\title{
Data report: bioerosion in the reef framework, IODP Expedition 310 off Tahiti (Tiarei, Maraa, and Faaa sites) ${ }^{1}$
}

\author{
Katrin Heindel, ${ }^{2}$ Hildegard Westphal, ${ }^{2}$ and Max Wisshak ${ }^{3}$
}

\section{Chapter contents}

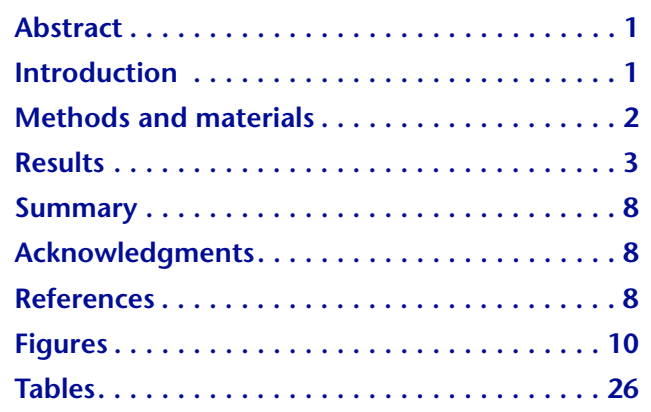

${ }^{1}$ Heindel, K., Westphal, H., and Wisshak, M., 2009. Data report: bioerosion in the reef framework, IODP Expedition 310 off Tahiti (Tiarei, Maraa, and Faaa sites). In Camoin, G.F., Iryu, Y., Mclnroy, D.B., and the Expedition 310 Scientists, Proc. IODP, 310: Washington, DC (Integrated Ocean Drilling Program Management International, Inc.). doi:10.2204/iodp.proc.310.201.2009 ${ }^{2}$ MARUM-Center for Marine Environmental Sciences, University of Bremen, Leobener Strasse, 28359 Bremen, Germany. Correspondence author: kheindel@uni-bremen.de

${ }^{3}$ GeoZentrum Nordbayern, Erlangen University, Loewenichstrasse 28, 91054 Erlangen, Germany.

\section{Abstract}

The coral reef framework off Tahiti was drilled during Integrated Ocean Drilling Program (IODP) Expedition 310 in order to study environmental change (including sea level rise) following the Last Glacial Maximum (LGM). Cores from sites located in the three drilling areas (Tiarei to the north, Faaa to the west, and Maraa to the southwest of the island of Tahiti) were studied in order to characterize the microbioerosion patterns in the post-LGM deglacial reef framework. A total of 19 samples were examined for information on environmental conditions directly after the demise of the shallow-water corals and during subsequent encrustation by coralline algae and microbialites. Microbioerosion patterns imply that conditions during reef growth were deeper euphotic to dysphotic. The reasons for the largely absent shallow euphotic indications lay in the proposed rapid sea level rise leaving a drowned reef in a "cryptophotic" position of most samples, in enhanced turbidity condensing the photic zonation, or in a combination of these factors. The sea level rise scenario combined with increased nutrient levels are considered the primary factors because entirely cryptophotic conditions of the sediment cores are less probable.

\section{Introduction}

During Integrated Ocean Drilling Program (IODP) Expedition 310, drowned Pleistocene-Holocene barrier reef terraces seaward of the modern fringing reefs of Tahiti were drilled in order to recover the deglacial reef sequence. The drilling strategy aimed at recovering cores along transects perpendicular to the strike direction of the reefs (Camoin et al., 2007). More than $600 \mathrm{~m}$ of core material was recovered (Camoin et al., 2007).

Tahiti is located at $17^{\circ} 50^{\prime} \mathrm{S}, 149^{\circ} 20^{\prime} \mathrm{W}$ in the central Pacific Ocean (French Polynesia, Society archipelago). A total of 19 samples from 14 holes from the three areas (Tiarei, Maraa, and Faaa) were studied. For the exact positions of the sites and samples studied see Tables T1 and T2. Terrestrial input of material eroded from the volcanic island is strongest in the Tiarei area, which is located close to the discharge of the largest drainage system of Tahiti, the mouth of the Papenoo River. The samples studied here are from sites in water depths up to $117 \mathrm{~m}$, whereas samples from sites located on ridges are in water depths of 56-81 m (Table T2; Fig. F1). 
Eleven samples were studied from the Tiarei area to the north, seven samples from Maraa to the south, and one sample from Faaa west of the island of Tahiti (Fig. F2). This study focuses on the post-Last Glacial Maximum (LGM) interval of the Expedition 310 cores. The typical repetitive pattern of the Tahitian post-LGM reef sequence consists of corals encrusted by coralline algae and subsequently by microbial crusts (Camoin et al., 2007). According to $\mathrm{U} / \mathrm{Th}$ age dates, the post-LGM interval is from 16,000 to 8,000 y before present (BP) (Camoin et al., 2007).

\section{Approach: bioerosion in marine carbonate substrates}

Bioerosion describes the erosion of marine hard substrates by living organisms via a number of mechanisms. Bioeroders are grazing organisms like gastropods, chitons, echinoids, and so on; sponges, bryozoans, worms, and so on (macroborers, trace diameter $>100 \mu \mathrm{m})$; and bacteria, algae, and fungi (microborers, trace diameter $<100 \mu \mathrm{m}$ ) (e.g., Golubic et al., 1975; Warme, 1975). Mechanisms of bioerosion include biotic boring, rasping, and scraping. The traces left by those bioerosive activities are classified as ichnotaxa and are highly sensitive paleoenvironmental indicators (Bromley, 2004; Glaub and Vogel, 2004). Microbioeroders are considered reliable paleoenvironmental indicators (temperature, light availability, and trophic conditions) because they are evolutionary conservative organisms (Vogel and Glaub, 2004).

For standardized interpretation of photic conditions, typical communities of microbioerosion traces have been defined (index ichnocoenoses) (Glaub, 1994, 1999; Vogel et al., 1995, 1999; Glaub et al., 2002; Vogel and Marincovich, 2004). Borings of the different photic zones show typical preferred orientations. In the shallower euphotic zones the penetration activities tend to be vertically oriented (e.g., Fascichnus isp. produced by the cyanobacterium Hyella spp.), whereas the traces found in deeper euphotic and dysphotic zones tend to be horizontally oriented (e.g., Ichnoreticulina elegans produced by the chlorophyte Ostreobium quekettii).

Three photic zones have been defined: the euphotic zone (>1\% surface illumination), dysphotic zone (0.01\%-1\% surface illumination), and aphotic zone $(<0.01 \%$ surface illumination) (Liebau, 1984; Glaub, 1994). The euphotic zone is divided into shallow euphotic Zones I, II, and III and the deep euphotic zone (Liebau, 1984; Glaub, 1994). Index ichnocoenoses describe most of the different photic zones. No index ichnocoenosis has been defined yet for shallow euphotic Zone I, but it is well known that this zone is typically dominated by cyanobacteria with sheath pigmentation. The Fascichnus acinosus/ Fascichnus dactylus ichnocoenosis is the typical vertically orientated trace community of shallow euphotic Zone II and is produced by cyanobacteria. The change from vertical to horizontal orientation of the borings starts with the index ichnocoenosis of shallow euphotic Zone III: F. dactylus/"Palaeoconchocelis starmachii." In shallow euphotic Zone III, microbioerosion is still dominated by traces of cyanobacteria but the traces now are horizontally orientated. Additionally, borings of eukaryotes are frequently encountered. The index ichnocoenoses of the deep euphotic zone is "P. starmachii"/I. elegans. Entirely, that zone shows the maximal trace diversity and is dominated by horizontally oriented bioerosion patterns of eukaryotes, mainly produced by rhodophytes and chlorophytes. The abundance of heterotrophs increases. The dysphotic zone is controlled by heterotrophs and the traces I. elegans (chlorophytes) and/or Scolecia filosa (cyanobacterium), whose producers can cope with very low illumination rates. The index ichnocoenosis of the dysphotic zone is not yet defined. Under aphotic conditions, bioerosion is limited to heterotrophic organisms. The index ichnocoenosis is composed of Saccomorpha clava/Orthogonum lineare (Glaub, 1994, 1999; Vogel and Marincovich, 2004; Wisshak, 2006).

\section{Methods and materials}

A total of 19 samples were selected for the study of microbioerosion in order to allow for the detection of trends along the deglacial succession from the LGM to the final drowning of the drilled coral reefs $(16,000-8,000$ y BP) (Camoin et al., 2007). Seven samples were taken close to the base of the deglacial (post-LGM) reef succession from Faaa, Maraa, and Tiarei; eight samples represent the middle part of the post-LGM reef from Maraa and Tiarei, and four samples represent the upper deglacial succession from Maraa and Tiarei (Table T2).

For taxonomic description of the bioerosion traces, the samples were impregnated with epoxy resin and subsequently dissolved, producing so-called casts of the bioerosion patterns inside the carbonate. For a detailed description of the vacuum-embedding technique after Golubic et al. (1970, 1983), see Beuck and Freiwald (2005) and Wisshak (2006). Determination of the bioerosion traces down to ichnospecies level was attempted where possible.

Two different methods of cast preparation were used. For the first method, selected samples were cut vertical to growth direction to cover the complete growth succession from corals to coralline algal crusts to 
microbialite crusts. Organic matter was eliminated with hydrogen peroxide followed by carbonate cleaning in the ultrasonic bath. After impregnating and curing the resin, the impregnated samples were etched shortly in hydrochloric acid (5\%) in order to remove only the uppermost $\sim 100 \mu \mathrm{m}$ of the carbonate substrate (coral, coralline algae, and microbialite). These casts were analyzed with respect to the vertical extension of microborings in the substrate, potential changes in the composition of the microbioeroder communities with progressive penetration depths, and substrate dependence of the microborer communities. For the second cast preparation method, other samples were taken from upper, not further encrusted surfaces of the substrate (coral and microbialite). The impregnated sample was completely dissolved in order to study superficial microbioerosion patterns and the horizontal extension of microbioerosion patterns. The casts of all samples were sputter-coated with gold for scanning electron microscopy (SEM) analysis. SEM images (Figs. F3, F4, F5, F6, F7, F8, F9, F10, F11, F12, F13, F14, F15) show resin casts of boreholes- "negatives" of the actual traces, which are boreholes inside the carbonate.

\section{Results}

In the following, a detailed inventory of the ichnotaxa is given. Traces which require further investigation are left in open nomenclature (e.g., "Dendrinidform").

\section{Spectrum of macrobioerosion}

Three ichnotaxa of macrobioeroders are present in corals, encrusting coralline algae, and in microbialites in the entire post-LGM reef. The sponge borings of the ichnogenus Entobia Bronn, 1837 (Fig. F3), are common to abundant in all samples. The producer of Entobia is the boring sponge Cliona and other Hadromerida. Additionally, domiciles of polychaetes have been identified. Caulostrepsis isp. is produced by the spionid worm Polydora, and the ichnospecies Maeandropolydora isp. is produced by the same or other polychaete worms.

\section{Spectrum of microbioerosion}

In typical Tahitian reef substrates of Expedition 310 (corals, encrusting coralline algae, and microbial crusts), a total of nine different traces of microborers were identified. Two main groups can be distinguished: traces of phototrophic euendoliths (cyanobacteria and chlorophytes) and traces of heterotrophic euendoliths (bacteria and fungi). The microbioerosion patterns produced by phototrophic organisms are dominated by cyanobacteria. These include Fascichnus dactylus (trace maker, e.g., Hyella caespitosa), Eurygonum nodosum (trace maker Mastigocoleus testarum), and Scolecia filosa (trace maker Plectonema terebrans). Additionally, ichnotaxa of chlorophytes were identified, including Rhopalia catenata (trace maker Phaeophila sp.) and Ichnoreticulina elegans (trace maker Ostreobium quekettii). The microborings produced by fungi are Saccomorpha clava and Saccomorpha cf. clava (both trace maker Dodgella priscus) and Orthogonum fusiferum (trace maker Ostracoblabe implexa). Ichnotaxa produced by unknown heterotrophic organisms identified during this study are Scolecia serrata, Scolecia cf. serrata, and Orthogonum lineare. Previously unknown traces produced by unknown organisms are the Dendrinid-form and the "worm-form."

Three samples were from aphotic habitats or more accurately referred to as "cryptophotic" habitats (cryptic and/or shaded habitats characterized by low light conditions within the otherwise euphotic reef; e.g., dead underside of corals, shaded crevices, etc.) (Heindel et al., in press), as is reflected by the identified heterotrophic microendoliths: Sample 310M0025A-9R-1, 22-29 cm, is from a downward surface of a coral, and Samples 310-M0025B-10R-1, 62$69 \mathrm{~cm}$, and 310-M0007B-11R-1, 54-60 cm, are from small cavities in coral framework encrusted by microbialite.

\section{Traces of phototrophic euendoliths \\ Traces produced by cyanobacteria}

Ichnotaxon Fascichnus dactylus (Radtke, 1991)

Fig. F4

Description: The trace was found in radiating bundles or larger carpets of up to $100 \mu \mathrm{m}$ long galleries $2-4 \mu \mathrm{m}$ in diameter. The relief of the galleries is smooth to slightly rough. Their distal ends are slightly thickened. Bifurcations were only rarely observed.

Distribution: In coral skeletons from the base of the deglacial succession: Faaa Sample 310-M0019A-9R-1, 65-70 $\mathrm{cm}$, and Maraa Samples 310-M0007B-26R-1, 77-92 cm, and 310-M0016A-35R-1, 23-27 cm.

Remarks: F. dactylus was exclusively found inside coral skeletons close to the substrate surface (upper tens of micrometers) and below the encrusting coralline algal crusts. Several extant trace makers are known for $F$. dactylus, the most abundant of which is Hyella caespitosa. The former name Fasciculus (nomen nudum) was replaced only recently by the new ichnogenus name Fascichnus by Radtke and Golubic (2005). 
Ichnotaxon Eurygonum nodosum Schmidt, 1992

Fig. F5

Description: The gallery diameter of this ichnospecies varies from 6 to $10 \mu \mathrm{m}$ and the traces are characterized by lateral swellings developed along the individual galleries in irregular intervals (heterocysts). These swellings are globular (7-15 $\mu \mathrm{m}$ in diameter). The repetitive bifurcations alternate from unilateral to bilateral mode with angles between $45^{\circ}$ and $90^{\circ}$.

Distribution: In coral skeletons from the base of the deglacial succession: Faaa Sample 310-M0019A-9R-1, 65-70 cm; Maraa Sample 310-M0016A-35R-1, 23-27 cm; and Tiarei Samples 310-M0024A-11R-2, 73-89 cm, and 310M0009D-9R-1, 108-114 cm.

Remarks: These microborings were exclusively observed inside corals up to $5 \mathrm{~mm}$ below the surface. The producer of E. nodosum is M. testarum.

\section{Ichnotaxon Scolecia filosa Radtke, 1991} Fig. F6

Description: S. filosa is characterized by "spaghetti-like" curved, thin (almost constantly $2 \mu \mathrm{m}$ in diameter), and long individual galleries forming large networks that are commonly found collapsed to the cast surface. They only rarely bifurcate.

Distribution: In corals, coralline algae, and microbialites from the base of the deglacial succession: Faaa Sample 310-M0019A-9R-1, 65-70 cm; Maraa Sample 310M0007B-26R-1, 77-92 cm, and Tiarei Samples 310M0024A-11R-2, 73-89 cm, and 310-M0009D-9R-1, 108$114 \mathrm{~cm}$. In corals, coralline algae, and microbialites from the middle ranges of the deglacial succession: Maraa Sample 310-M0018A-1R-1, 41-47 cm, and Tiarei Samples 310M0024A-1R-1, 3-6 cm, 310-M0021B-2R-1, 96-103 cm, 310-M0009B-1R-1, 33-46 cm, and 310-M0009E-3R-1, 99$110 \mathrm{~cm}$. In corals, coralline algae, and microbialites from the top of the deglacial succession: Tiarei Samples 310M0023A-2R-1, 40-47 cm, and 8R-1, 5-41 cm.

Remarks: $S$. filosa was identified in all three reef framework elements but is mostly present inside coral skeletons and less in coralline algae. The boring organism producing this trace is the cyanobacteria P. terebrans.

\section{Traces produced by chlorophytes}

\section{Ichnotaxon Rhopalia catenata Radtke, 1991 Fig. F7}

Description: The type of $R$. catenata in the present substrates is characterized by $5-7 \mu \mathrm{m}$ thick galleries. Different pronounced swellings (5-20 $\mu \mathrm{m}$ in diameter) occur in irregular intervals along the galleries and are connected to the substrate surface by short rhizoidal appendixes $(2 \mu \mathrm{m})$. The swellings appear from oval (egg-shaped) to nodular/ spheroidal, whereas the latter morphology is mostly more pronounced than the oval form. The bifurcations of $R$. catenata are dichotomous (angles between $45^{\circ}$ and $60^{\circ}$ ).

Distribution: In coral skeletons from the base of the deglacial succession: Maraa Sample 310-M0007B-26R-1, 77$92 \mathrm{~cm}$, and Tiarei Sample 310-M0009D-9R-1, 108-114 cm.

Remarks: $R$. catenata is produced by Phaeophila sp. and occurs in the investigated Tahitian reef samples exclusively in corals at a maximum depth similar to E. nodosum (as deep as $5 \mathrm{~mm}$ ).

\section{Ichnotaxon Ichnoreticulina elegans (Radtke, 1991)} Fig. F8

Description: The morphology of I. elegans is highly complex (Radtke and Golubic, 2005). The typical zigzag pattern is the most obvious feature of I. elegans. From a parallel and close to the substrate surface extending straight or winding main first-order gallery (4-5 $\mu \mathrm{m}$ in diameter), second- and third-order galleries develop mainly at right angles and form large and dense zigzag-shaped networks $(2-5 \mu \mathrm{m})$. Thin and straight "exploratory" filaments $(1-2 \mu \mathrm{m})$ extend from the same colony. In some cases little appendixes $(\leq 1 \mu \mathrm{m})$ emerge from individual first-order galleries (e.g., in Maraa Sample 310-M0007B26R-1, 77-92 cm, and Tiarei Sample 310-M0023A-2R-1, $40-47 \mathrm{~cm}$ ). Some thick galleries (as thick as $5 \mu \mathrm{m}$ ) show archlike branches which connect I. elegans with the substrate surface (cf., Radtke and Golubic, 2005). The individual arches span a distance of 10-20 $\mu \mathrm{m}$.

Distribution: In corals, coralline algae, and microbialites from the base of the deglacial succession: Maraa Samples 310-M0007B-26R-1, 77-92 cm, and 310-M0016A35R-1, 23-27 cm; and Tiarei Samples 310-M0024A-11R-2, 73-89 cm, and 310-M0009D-9R-1, 108-114 cm. In corals, coralline algae, and microbialites from the middle ranges of the deglacial succession: Maraa Samples 310-M0015A9R-1, 6-10 cm, 310-M0018A-1R-1, 41-47 cm, and 6R-1, 6$10 \mathrm{~cm}$; and Tiarei Samples 310-M0024A-1R-1, 3-6 cm, 310M0021B-2R-1, 96-103 cm, 310-M0009B-1R-1, 33-46 cm, and 310-M0009E-3R-1, 99-110 cm. In corals, coralline algae, and microbialites from the top of the deglacial succession: Maraa Sample 310-M0017A-5R-1, 28-32 cm, and Tiarei Samples 310-M0023A-2R-1, 40-47 cm, 3R-1, 10-12 $\mathrm{cm}$, and 8R-1, 5-41 cm.

Remarks: I. elegans is produced by O. quekettii. The former ichnogenus name Reticulina (nomen nudum) was substituted by Ichnoreticulina only recently by Radtke and Golubic (2005).

\section{Traces of heterotrophic euendoliths Traces produced by fungi}

\section{Ichnotaxon Saccomorpha clava Radtke, 1991} Fig. F9A-F9D

Description: Sphere-, pear- and club-shaped sacks (up to $30 \mu \mathrm{m}$ long) connected to the surface by a narrow neck, usually lacking a collar, were identified as $S$. clava. The in- 
dividual sacks are interlinked by one or several thin filaments originating from the main sack or at the base of the necks. Four morphotypes exist in the analyzed reef substrates: (1) scattered straight or (2) curved sacks (both 10$15 \mu \mathrm{m}$ in diameter), (3) clusters of mainly sphere- and club-shaped sacks (10-15 $\mu \mathrm{m}$ in diameter), and (4) large individual branched sacks (20-30 $\mu \mathrm{m}$ in diameter).

Distribution: In corals and microbialites from the base of the deglacial succession: Tiarei Samples 310-M0025A9R-1, 22-29 cm, and 310-M0025B-10R-1, 62-69 cm. In corals and microbialites from the middle ranges of the deglacial succession: Maraa Samples 310-M0015A-9R-1, 6-10 $\mathrm{cm}$, and 310-M0018A-6R-1, 6-10 cm; and Tiarei Samples 310-M0009B-1R-1, 33-46 cm, and 310-M0009E-3R-1, 99$110 \mathrm{~cm}$. In corals and microbialites from the top of the deglacial succession: Maraa Samples 310-M0007B-11R-1, 54$60 \mathrm{~cm}, 310-M 0017 \mathrm{~A}-5 \mathrm{R}-1,28-32 \mathrm{~cm}$; and Tiarei Samples 310-M0023A-2R-1, 40-47 cm, 3R-1, 10-12 cm, and 8R-1, $5-41 \mathrm{~cm}$.

Remarks: S. clava was found independent of photic conditions in all photic zones in the entire deglacial reef sequence. The presumed trace maker of this ichnospecies is $D$. priscus, whereas in the present case this may not apply to all morphological variants.

\section{Ichnotaxon Saccomorpha cf. clava}

Fig. F9E, F9F

Description: Generally, the morphology is comparable to Morphotypes 2 and 3 of $S$. clava (see above), but $S$. cf. clava is longer and slightly thicker (30-60 $\mu \mathrm{m}$ long and 10$20 \mu \mathrm{m}$ in diameter). Figure F9E shows one specimen with several noticeably long and thin filaments originating mainly from the base of the neck.

Distribution: In corals from the base of the deglacial succession: Tiarei Sample 310-M0009D-9R-1, 108-114 cm. In microbial crusts from the middle ranges of the deglacial succession: Maraa Sample 310-M0018A-1R-1, 41-47 cm. In coral skeletons from the top of the deglacial succession: Tiarei Sample 310-M0023A-8R-1, 5-41 cm.

Remarks: Same as for $S$. clava, D. priscus, may be the producer of this morphological variant.

\section{Ichnotaxon Orthogonum fusiferum Radtke, 1991}

Fig. F10

Description: Thin straight to slightly winding galleries ( $2 \mu \mathrm{m}$ in diameter) with typical swellings $(3-5 \mu \mathrm{m}$ in diameter) along the galleries or at the mostly perpendicular bifurcations.

Distribution: In corals from the middle ranges of the deglacial succession: Tiarei Sample 310-M0009B-1R-1, 33$46 \mathrm{~cm}$. In corals from the top of the deglacial succession: Tiarei Sample 310-M0023A-8R-1, 5-41 cm.

Remarks: The trace is produced by Ostracoblabe implexa and was exclusively found in corals of the upper deglacial succession with prevailing dysphotic conditions.
Traces produced by unknown heterotrophs

\section{Ichnotaxon Scolecia serrata Radtke, 1991}

Fig. F11

Description: This trace is the thinnest of all the observed ichnotaxa $(\sim 1 \mu \mathrm{m}$ in diameter) and shows a characteristic serrate microsculpture. $S$. serrata forms dense often interconnected networks in very narrow windings parallel to the substrate surface.

Distribution: In corals, coralline algae, and microbialites from the base of the deglacial succession: Maraa Sample 310-M0007B-26R-1, 77-92 cm, and Tiarei Samples 310-M0025B-10R-1, 62-69 cm, and 310-M0024A-11R-2, $73-89 \mathrm{~cm}$. In corals, coralline algae, and microbialites from the middle ranges of the deglacial succession: Maraa Samples 310-M0015A-9R-1, 6-10 cm, 310-M0018A-1R-1, 41-47 $\mathrm{cm}$, and 6R-1, 6-10 cm; and Tiarei Samples 310-M0024A1R-1, 3-6 cm, 310-M0021B-2R-1, 96-103 cm, and 310M0009E-3R-1, 99-110 cm. In corals, coralline algae, and microbialites from the top of the deglacial succession: Maraa Sample 310-M0017A-5R-1, 28-32 cm, and Tiarei Samples 310-M0023A-2R-1, 40-47 cm, 3R-1, 10-12 cm, and $8 \mathrm{R}-1,5-41 \mathrm{~cm}$.

Remarks: As in recent settings, S. serrata is frequently associated with I. elegans, where its galleries run at the surface and in between the thicker tubes of I. elegans (Fig. F11E). The producer is an unknown heterotrophic organism probably belonging to filamentous bacteria (Budd and Perkins, 1980).

\section{Ichnotaxon Scolecia cf. serrata}

Fig. F12

Description: This unusual appearance of $S$. serrata shows the typical serrate microsculpture with rare bifurcations, but the galleries of $S$. cf. serrata are slightly thicker $(\sim 2 \mu \mathrm{m}$ in diameter) and they often form spherical aggregates resembling "bags of wool." In the latter, narrow windings of galleries seem to twine around spherelike traces such as Saccomorpha sphaerula, the emerging hyphae of which are clearly visible. Nevertheless, the association of spherical buildings of larger diameter filaments with radiating very thin filaments is unique and quite distinct from the usual prostrate and space-filling habit of $S$. serrata. Therefore, this trace might refer to a new ichnotaxon. However, this type of trace (association of two traces?) was only found in one current sample. There is no "fossil affirmation" (older than the last deglacial). Future studies are required to introduce a new ichnotaxon.

Distribution: Exclusively in the coral part of Maraa Sample 310-M0017A-5R-1, 28-32 cm, from the top of the deglacial succession.

Remarks: Since this trace is regarded as a (previously unknown) morphological variant of $S$. serrata, the same unknown (bacterial?) heterotrophic producer can be assumed. 
Ichnotaxon Orthogonum lineare Glaub, 1994 Fig. F13

Description: $O$. lineare has a perpendicular bifurcation pattern with 8-10 $\mu \mathrm{m}$ thick galleries without swellings. Casually, short spiny protrusions (apophysis; Fig. F13C, F13D) protrude from the main galleries.

Distribution: In corals, coralline algae, and microbialites from the base of the deglacial succession: Tiarei Samples 310-M0025A-9R-1, 22-29 cm, and 310-M0025B10R-1, 62-69 cm. In corals, coralline algae, and microbialites from the middle ranges of the deglacial succession: Maraa Sample 310-M0015A-9R-1, 6-10 cm, and Tiarei Samples 310-M0009B-1R-1, 33-46 cm, and 310-M0009E3R-1, 99-110 cm. In corals, coralline algae, and microbialites from the top of the deglacial succession: Maraa Sample 310-M0017A-5R-1, 28-32 cm, and Tiarei Sample 310-M0023A-2R-1, 40-47 cm.

Remarks: In contrast to most recent occurrences of this trace, the present traces are abundantly not smooth but rather verrucose (tiny knots arranged closely along the galleries). The uncommon zigzaglike course of individual galleries of $O$. lineare is probably caused by the parallel run to Entobia boring cells and/or coralline algae cells (Fig. F13A, F13B). The producer of $O$. lineare is an unknown heterotrophic organism.

\section{Traces of unknown affinity}

\section{Ichnotaxon Dendrinid-form} Fig. F14

Description: A central gallery bifurcates in a dendriniform pattern often at right angles and forms a dense network parallel to the substrate surface. The microborings have developed a zigzag pattern otherwise typical for I. elegans but are much larger in diameter $(10-15 \mu \mathrm{m})$. The surface of the individual galleries appears rough.

Distribution: Identified exclusively in Entobia cavities of the coral part in Tiarei Sample 310-M0023A-2R-1, 40-47 $\mathrm{cm}$, from the top of the deglacial succession.

Remarks: This trace shows some affinity to dendrinid ichnospecies subsumed under the ichnofamily Dendrinidae (Bromley et al., 2007). The producer is unknown.

\section{Ichnotaxon worm-form} Fig. F15

Description: This previously unknown microboring shows a complex morphology with widening galleries, from which a lateral prolongation of the main gallery emerges close to their rounded ends, and the pattern is repeated in reduced dimension. The basal galleries reach diameters of up to $40 \mu \mathrm{m}$, whereas the more distal galleries are only few micrometers in diameter.

Distribution: In microbialite from the base of the deglacial succession: Tiarei Sample 310-M0025B-10R-1, 62$69 \mathrm{~cm}$. In microbial crust from the middle ranges of the deglacial succession: Maraa Sample 310-M0015A-9R-1, 6$10 \mathrm{~cm}$.
Remarks: The producer is unknown and it is not entirely conclusive whether these casts actually represent a previously unknown microboring or rather a cast of a calcareous epizoan, such as a polychaete worm, or a linear bryozoan colony.

\section{Relative abundances and paleobathymetric significance}

The mean abundances of all traces in the coral skeletons are higher than those in microbialites and coralline algal crusts. On average, S. filosa, I. elegans, and $S$. clava are common, whereas $F$. dactylus, E. nodosum, $R$. catenata, S. cf. clava, O. fusiferum, S. serrata, S. cf. serrata, O. lineare, and Dendrinid-form are rare. In coralline algal crusts, S. filosa, I. elegans, S. serrata, and $O$. lineare are rarely encountered, whereas all other traces are absent. In microbialites, S. filosa, I. elegans, S. clava, S. cf. clava, S. serrata, O. lineare, and wormform are found in low mean abundance, whereas $F$. dactylus, E. nodosum, $R$. catenata, O. fusiferum, S. cf. serrata, and Dendrinid-form are absent.

In total, I. elegans is the most frequent ichnotaxon with a presence in $79 \%$ of the analyzed samples, followed by $S$. serrata (68\%), S. filosa and S. clava $(58 \%$ each), O. lineare (42\%), E. nodosum (21\%), and F. dactylus and $S$. cf. clava (16\% each). R. catenata, $O$. fusiferum, and worm-form show presences in $11 \%$ each. The least frequent traces are $S$. cf. serrata and Dendrinid-form (5\% each).

\section{Microbioerosion at the base of deglacial succession}

Microbioerosion patterns in corals at the base of the deglacial succession are dominated by light-dependent cyanobacterial traces. F. dactylus, E. nodosum, and $S$. filosa are common at Faaa, whereas the sole heterotrophic trace $O$. lineare is rare. In the Maraa area, the cyanobacterial traces occur in varying abundances: $F$. dactylus from rare to common and $E$. nodosum and $S$. filosa from common to abundant. The chlorophytal traces $R$. catenata and I. elegans are abundant. At Maraa, the only heterotrophic trace observed in corals is $S$. serrata with common abundance. In the Tiarei area, E. nodosum and S. filosa are common, whereas the sole chlorophytal trace $I$. elegans is rare. The fungal S. clava is common, whereas $S$. cf. clava and the traces of unknown heterotrophic producers $S$. serrata and $O$. lineare are rare (Table T3).

The trace associations in coralline algal crusts at the Maraa sites are dominated by common I. elegans and $S$. serrata, whereas $S$. filosa is very rare. At Tiarei sites, $S$. filosa, I. elegans, S. serrata, and O. lineare are all rare. At Faaa, only the bioerosion patterns that were found inside coral skeletons could be identified with confidence (Table T3). 
The trace associations in microbialites at the base of the deglacial succession at Maraa sites are dominated by the common ichnotaxon I. elegans, whereas $S$. filosa and $S$. serrata are rare. At Tiarei, the microbioerosion inventory is dominated by the common fungal trace $S$. clava, whereas $S$. filosa, I. elegans, S. serrata, O. lineare, and worm-form are rare (Table T3).

The key ichnotaxon of shallow euphotic Zones II and III, $F$. dactylus, was found exclusively in the sample from Faaa and in two samples from Maraa. The horizontally oriented traces $E$. nodosum and $R$. catenata are known to be common in shallow euphotic Zone III and the deeper euphotic zone (Vogel and Marincovich, 2004) and are considered indicative of these zones. In analyzed samples, F. dactylus, E. nodosum, and $R$. catenata are the ichnotaxa with the shallowest photic indication and were found exclusively inside coral skeletons and at the base of the deglacial reef succession. Traces produced by microborers that cope with very low illumination rates (dysphotic conditions), S. filosa and I. elegans, were found in all three substrates alongside traces of heterotrophic bioerosion agents such as $S$. serrata and $O$. lineare (cryptophotic conditions). The fungal trace $S$. clava was not identified in coralline algae, whereas the other fungal trace $O$. fusiferum was not found at all at the base of the succession.

In summary, at the base of the deglacial succession differential microbioerosion patterns were observed in the various substrates with microbioerosion in corals indicating shallow euphotic Zone II to deep euphotic conditions, whereas microbioeroders in coralline algae and microbialites imply dysphotic conditions (except from microhabitats with prevailing cryptophotic conditions) (Table T3).

Along the deglacial succession, the changing bioerosion patterns are outlined in the following. In contrast to the base of the succession, the main photic indication of the trace patterns found in all three substrates (corals, coralline algae, and microbialites) from the middle to the top ranges of the post-LGM is dysphotic. Traces of microbioeroders typical for euphotic conditions are completely absent in the younger part of the succession (Table T4, T5; Fig. F16).

\section{Microbioerosion in the middle ranges of deglacial succession}

Microbioerosion patterns in corals in the middle ranges of the deglacial succession are composed of traces produced by low-light specialists and by traces of microbioeroders penetrating in the dark. On average, all identified ichnotaxa are common at Maraa: $S$. filosa, I. elegans, S. clava, S. serrata, and O. lineare. At Tiarei sites, the most frequent traces are I. elegans (abundant), S. filosa (common), and S. clava (common), whereas $S$. serrata and $O$. lineare are rare to common and O. fusiferum is rare (Table T4).

In coralline algal crusts, the trace associations at Maraa and Tiarei sites are composed of $S$. filosa, I. elegans, $S$. serrata, and $O$. lineare. All observed traces are rare (Table T4).

The trace associations in microbial crusts at Maraa and Tiarei consist of $S$. filosa, I. elegans, S. clava, S. cf. clava, S. serrata, O. lineare, and worm-form. At Maraa, I. elegans, S. serrata, and O. lineare show common abundances, whereas all other ichnotaxa are rare. At Tiarei, $I$. elegans and $S$. clava are also represented commonly in microbialites, whereas other ichnotaxa are rare (Table T4).

\section{Microbioerosion at the top of deglacial succession}

The top of the deglacial succession is mainly characterized by microborings with dysphotic indication (cf. the middle ranges; Table T5, Fig. F16). In the youngest part of the deglacial reef sequence, the mean diversity of traces is strongly reduced when compared to the base and slightly reduced when compared to the middle ranges.

The trace associations in corals are dominated at Maraa by the abundant I. elegans and $S$. serrata, whereas $O$. lineare and $S$. cf. serrata are common and $S$. clava is rare. At Tiarei, I. elegans and $S$. clava are abundant, whereas $S$. filosa is common and $O$. fusiferum, $S$. serrata, and Dendrinid-form are rare (Table T5).

Coralline algal crusts at Maraa show no signs of microbioerosion. At Tiarei sites, all identified ichnotaxa (S. filosa, I. elegans, S. serrata, and O. lineare) are rare (Table T5).

In microbial crusts at the top of the succession of Maraa, I. elegans is common, whereas S. serrata, S. clava, and $O$. lineare are rare. Microbialites at Tiarei from the top of the succession are composed of common I. elegans and S. clava as well as rare S. filosa, $S$. serrata, and $O$. lineare (Table T5).

The traces $S$. filosa and I. elegans produced by lowlight specialists (cyanobacterium $P$. terebrans, chlorophyte $O$. quekettii) are known to thrive down to the dysphotic zone (Vogel and Marincovich, 2004). Both ichnotaxa were found along with traces of heterotrophic origin (see below) throughout the entire Tahitian deglacial reef sequence and in all three framework elements. This indicates dysphotic conditions for the deposition of the middle and upper part 
of the deglacial reef sequence (Table T4, T5). The producer of $S$. serrata is a heterotrophic organism and was observed in all substrates, apparently independent of photic conditions. O. lineare was also identified in the entire Tahitian reef succession and occurs mainly inside Entobia cavities (Fig. F13). S. clava and $O$. fusiferum produced by fungi are present in coral and microbialite samples independent of sampling positions. However, the abundances of all heterotrophic traces are most pronounced in cryptophotic microhabitats: dead underside of corals, deep inside the coral porosity, and in Entobia cavities (Sample 310-M0007B-11R-1, 54-60 cm, from the upper part of the reef and Samples 310-M0025A-9R-1, 22-29 cm, and 310-M0025B-10R-1, 62-69 cm, from the base of the deglacial reef; Fig. F16).

\section{Summary}

The present results and specifically the lack of shallow euphotic indications in the bioerosion ichnocoenoses through the middle and upper deglacial reef succession can be attributed to three possible causes or their combination:

1. The microbioerosion patterns are in good agreement with the notion of a rapid deglacial sea level rise when considering that only the ichnocoenoses developed in corals at the base of the succession indicate shallow euphotic Zone II to deep euphotic conditions present during relative sea level lowstand. The deepening-up effect is demonstrated by the ichnocoenoses found in corals, coralline algae, and microbial crusts from the middle and top ranges of the deglacial succession, which reflect dysphotic conditions due to reef growth progressively lagging behind sea level rise (Fig. F16). Furthermore, encrustation of the coral framework by microbialites soon after the demise of the corals is indicated by the similar photic conditions in corals and microbialites as indicated by ichnocoenoses.

2. Most of the recorded ichnocoenoses were not established in deeper waters but partly in cryptic and shaded areas of the otherwise photic reef (dead underside of corals, small cavities, shaded crevices, etc.) and thus are better labeled cryptophotic. This particularly applies to the cases of algal crusts and microbialites that-at least at the base of the reef succession-show ichnotaxa, indicating a lower illumination state if compared to encrusted coral skeletons. However, the implications on the timing of microbialite versus coral growth is not entirely conclusive because the contemporaneous development in the cryptic scenario can not be distinguished from the delayed microbialite growth after sea level rise, based solely on the ichnocoenosis composition.

3. Another potential factor capable of causing low illumination states in relatively shallow water is a decrease in water transparency due to an increase in nutrient level and sediment input by local river runoff. This model would explain the co-occurrence of mesotrophic/eutrophic microbialites on the one hand and zooxanthellate corals (weakened by rapid sea level rise?) on the other.

The relative importance of these possible causes will be evaluated when integrating other data such as reliable radiocarbon dating and sedimentological proxies in further studies (cf., Heindel et al., in press). Nevertheless, the sea level rise scenario combined with elevated nutrient levels are tentatively considered the primary factors because entirely cryptophotic conditions of the sediment cores are less probable.

\section{Acknowledgments}

This research used samples and/or data provided by the Integrated Ocean Drilling Program (IODP). The authors would like to thank the Expedition 310 Scientific Party, the co-chiefs G. Camoin and Y. Iryu, and the staff of the Bremen Core Repository. The MARUM (DFG-Research Center/Excellence Cluster "The Ocean in the Earth System") is acknowledged for providing infrastructure and support for this research. Many thanks to Stjepko Golubic for his very helpful and constructive comments and to Gilles Lericolais (Ifremer, Brest) for help with the seismic data. SEM analyses were undertaken in the laboratory of André Freiwald, GeoZentrum Nordbayern (Erlangen University). Funding for this research was provided by German Science Foundation (DFG) project We $2492 / 5$ to HW. HW is a member of the Expedition 310 Scientific Party.

\section{References}

Beuck, L., and Freiwald, A., 2005. Bioerosion patterns in a deep-water Lophelia pertusa (Scleractinia) thicket (Propeller Mound, northern Porcupine Seabight). In Freiwald, A., and Roberts, J.M. (Eds.), Cold Water Corals and Ecosystems: Heidelberg (Springer-Verlag), 915-936.

Bromley, R.G., 2004. A stratigraphy of marine bioerosion. In McIlroy, D. (Ed.), The Application of Ichnology to Palaeoenvironmental and Stratigraphic Analysis. Geol. Soc. Spec. Publ., 228(1):455-479. doi:10.1144/ GSL.SP.2004.228.01.20

Bromley, R.G., Wisshak, M., Glaub, I., and Botquelen, A., 2007. Ichnotaxonomie review of dendriniform borings 
attributed to foraminiferans: Semidendrina igen. nov. In Miller, W., III (Ed.), Trace Fossils: Concepts, Problems, Prospects: Amsterdam (Elsevier), 518-530.

Bronn, H.G., 1837. Lethaea Geognostica: Abbildungen und Beschreibungen der für die Gebirge-Formationen Bezeichnendsten Versteinerungen: Schweizerbart, Stuttgart (Schweizerbart).

Budd, D.A., and Perkins, R.D., 1980. Bathymetric zonation and paleoecological significance of microborings in Puerto Rican shelf and slope sediments. J. Sediment. Petrol., 50(3):881-904.

Camoin, G.F., Cabioch, G., Hamelin, B., and Lericolais, G., 2003. Rapport de mission SISMITA. Institut de recherche pour le développement, Papeete, Polynesia Francaise.

Camoin, G.F., Iryu, Y., McInroy, D.B, and the IODP Expedition 310 Scientists, 2007. IODP Expedition 310 reconstructs sea level, climatic, and environmental changes in the South Pacific during the last deglaciation. Sci. Drill., 5:4-12. doi:10.2204/iodp.sd.5.01.2007

Glaub, I., 1994. Microspores in selected deposits of the European Jurassic and the Lower Creatceous: classification and paleontology. CFS, Cour. Forschungsinst. Senckenberg, 174.

Glaub, I., 1999. Paleobathymetric reconstructions and fossil microborings. Bull. Geol. Soc. Den., 45:143-146.

Glaub, I., Gektidis, M., and Vogel, K., 2002. Microborings from different North Atlantic shelf areas-variability of the euphotic zone extension and implications for paleodepth reconstructions. CFS, Cour. Forschungsinst. Senckenberg, 237:25-37.

Glaub, I., and Vogel, K., 2004. The stratigraphic record of microborings. Fossils Strata, 51:126-135.

Golubic, S., Brent, G., and LeCampion, T., 1970. Scanning electron microscopy of endolithic algae and fungi using a multipurpose casting-embedding technique. Lethaia, 3(2):203-209. doi:10.1111/j.1502-

3931.1970.tb01858.x

Golubic, S., Campbell, S., and Spaeth, C., 1983. Kunstharzausgüsse fossiler Mikroben-Bohrgänge. Präparator, 29:197-200.

Golubic, S., Perkins, R.D., and Lukas, K.J., 1975. Boring microorganisms and microborings in carbonate substrates. In Frey, R.W. (Ed.), The Study of Trace Fossils: New York (Springer-Verlag), 229-259.
Heindel, K., Wisshak, M., and Westphal, H., in press. Microbioerosion in Tahitian reefs: a record of environmental change during the last deglacial sea level rise (IODP 310). Lethaia. www.itp.uni-bremen.de/complex/hw/Heindel_et_al_2008.pdf

Liebau, A., 1984. Grundlagen der Ökobathymetrie. In Luterbacher, H. (Ed.), Paläobathymetrie. Palaeontol. Kursb., 2:149-184.

Radtke, G., 1991. The microendolithic trace fossils in the lower Tertiary of Western Europe and their paleontological significance. CFS, Cour. Forschungsinst. Senckenberg, 138.

Radtke, G., and Golubic, S., 2005. Microborings in mollusk shells, Bay of Safaga, Egypt: morphometry and ichnology. Facies, 51(1-4):118-134. doi:10.1007/s10347-0050016-02

Schmidt, H., 1992. Mikrobohrspuren ausgewählter faziesbereiche der tethyalen und germanischen trias (Beschreibung, Vergleichund und bathymetrische interpretation). Frankf. Geowiss. Arb. A, 12:1-228.

Vogel, K., Balog, S.-J., Bundschuh, M., Gektidis, M., Glaub, I., Krutschinna, J., and Radtke, G., 1999. Bathymetrical studies in fossil reefs, with microendoliths as paleoecological indicators. Profil, 16:181-191.

Vogel, K., Bundschuh, M., Glaub, I., Hofmann, K., Radtke, G., and Schmidt, H., 1995. Hard substrate ichnocoenoses and their relations to light intensity and marine bathymetry. Neues Jahrb. Geol. Palaeontol., Abh., 195(1-3):49-61.

Vogel, K., and Glaub, I., 2004. 450 million years of continuous evolution of endolithic microorganisms? Sitzungsber. Wiss. Ges. Univ. Frankfurt, 42(1).

Vogel, K., and Marincovich, L., Jr., 2004. Paleobathymetric implications of microborings in Tertiary strata of Alaska, USA. Palaeogeogr., Palaeoclimatol., Palaeoecol., 206(12):1-20. doi:10.1016/j.palaeo.2003.12.017

Warme, J.E., 1975. Borings as trace fossils, and the process of marine bioerosion. In Frey, R.W. (Ed.), The Study of Trace Fossils: New York (Springer-Verlag), 181-227.

Wisshak, M., 2006. High-Latitude Bioerosion: The Kosterfjord Experiment: Heidelberg (Springer-Verlag), 109.

Initial receipt: 9 April 2008

Acceptance: 25 August 2008

Publication: 23 January 2009

MS 310-201 
Figure F1. Seismic line of Tiarei area. Note series of drowned reefs forming submarine ridges (relative age of drowned reefs given by numbers 13) and volcaniclastic sediment bodies shed from the island of Tahiti. Seismic data are from the site survey (Camoin et al., 2003) provided from the IODP Site Survey Data Bank (ssdb.iodp.org).

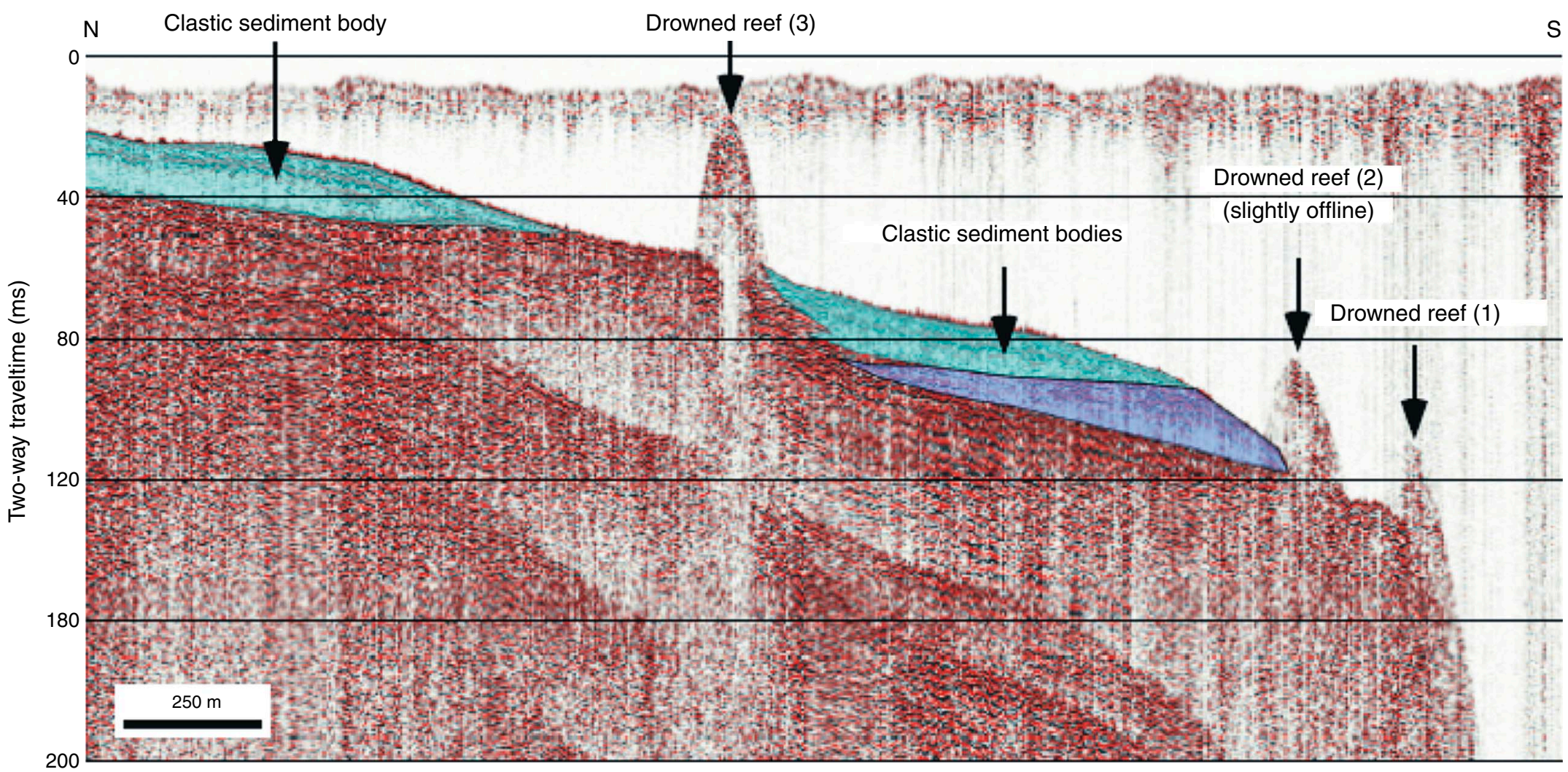


Figure F2. Tahiti map including Tiarei, Faaa, and Maraa areas (slightly modified after Camoin et al., 2003, and Heindel et al., in press).

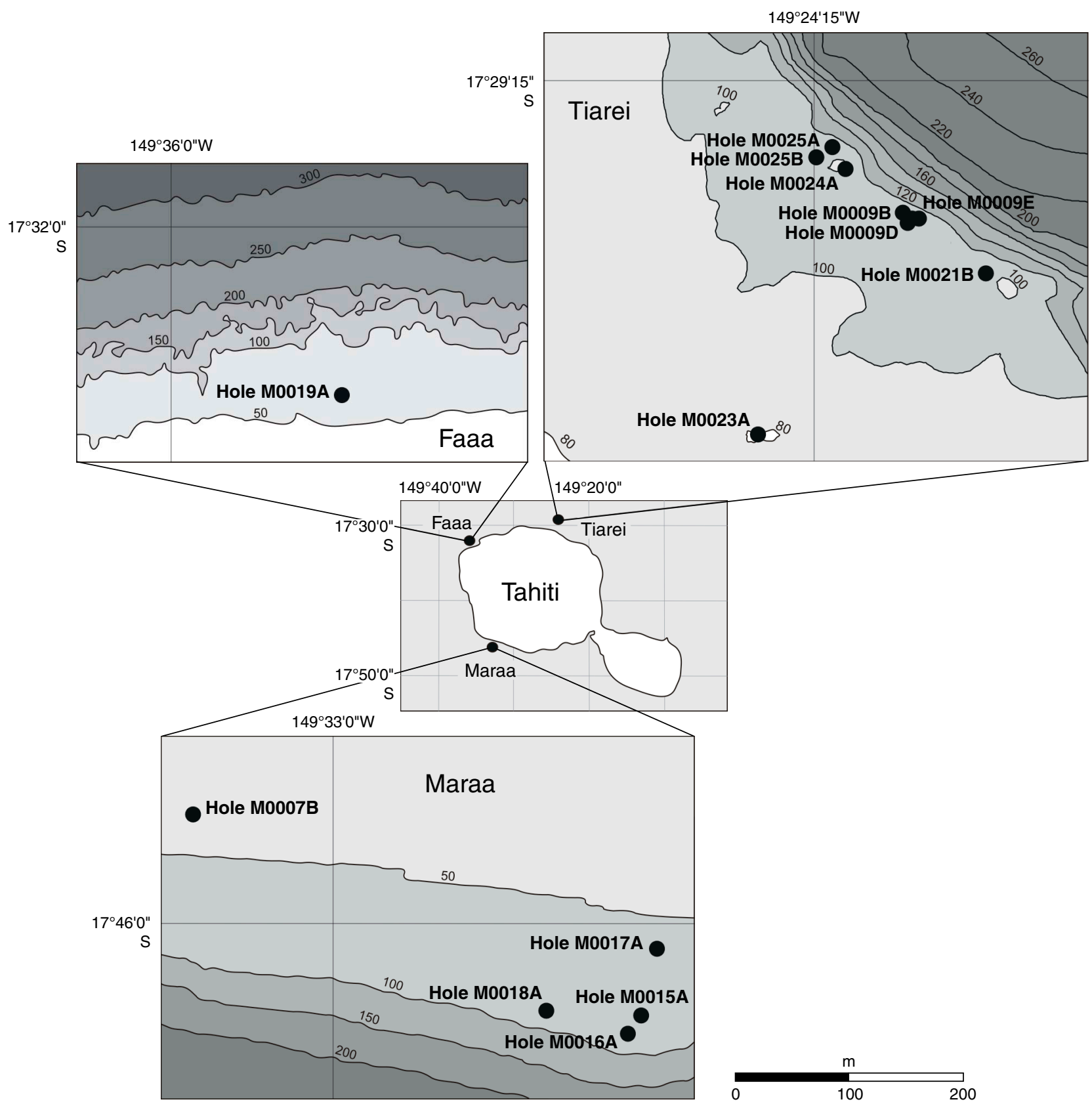


Figure F3. Entobia isp. (SEM images of resin casts, "negatives" of boreholes inside the carbonate) produced by clionaid sponges. Fine filamentous casts/traces likely represent borings of the endolithic green alga Ostreobium. A. Large Entobia chambers show a verrucose surface sculpture, imprints of carbonate-carving cells. B. Exploratory extensions emanating from large Entobia chamber. C. Exploratory Entobia tunnel. D. Detail of exploratory extension. E. Detail of scars left by carbonate-carving sponge cells. Note concentric surface feature marking the progression of cell margins carving carbonate chips. F. Tip of Entobia exploratory tunnel protruding from coral skeleton.
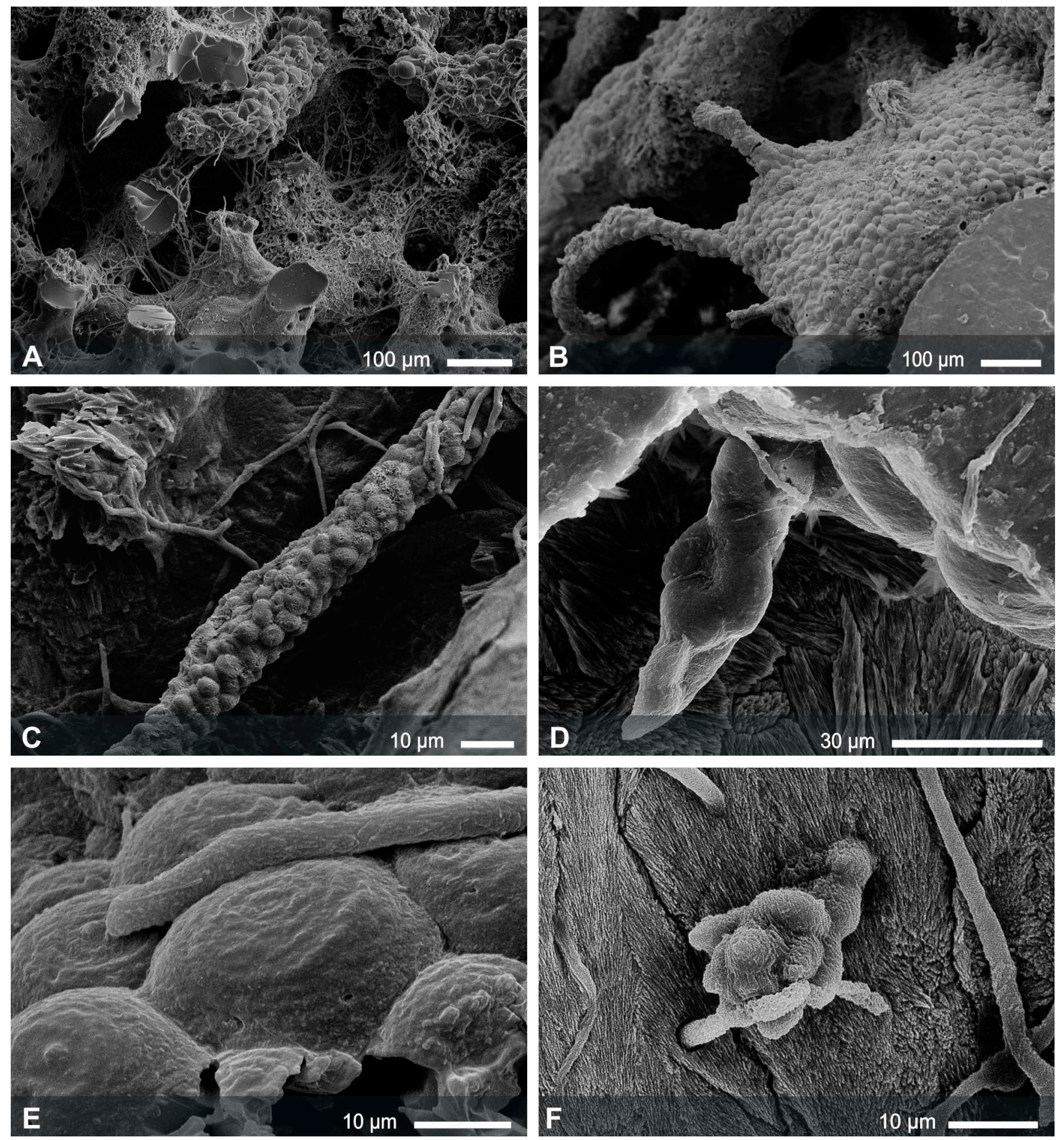
Figure F4. A, B. Fascichnus dactylus (SEM images of resin casts of boreholes) colonies produced by the cyanobacterium Hyella caespitosa and related species. Typical thick and short galleries of $F$. dactylus with indicated cell walls. F. dactylus is recorded solely in coral skeletons from Tahiti deglacial coral reefs (SEM).
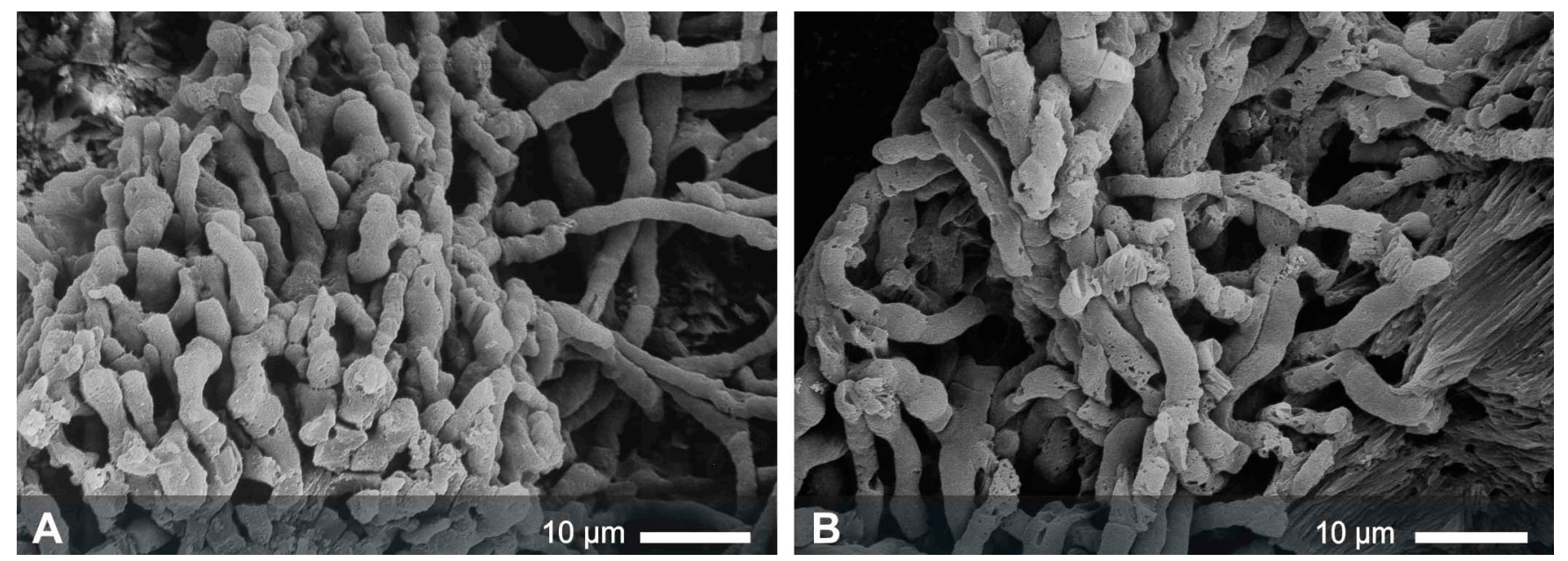
Figure F5. A-D. Eurygonum nodosum (SEM images of resin casts of boreholes), a trace produced by the cyanobacterium Mastigocoleus testarum. The frequently bifurcated trace produces filamentous casts of variable diameter and develops characteristic lateral swellings, which harbor heterocysts (arrows), the nitrogen-fixing cells. B. Short lateral branch probably containing heterocysts (arrow). C, D. Variations in E. nodosum borings. E. nodosum is exclusively recorded in coral skeletons from Tahiti deglacial coral reefs.
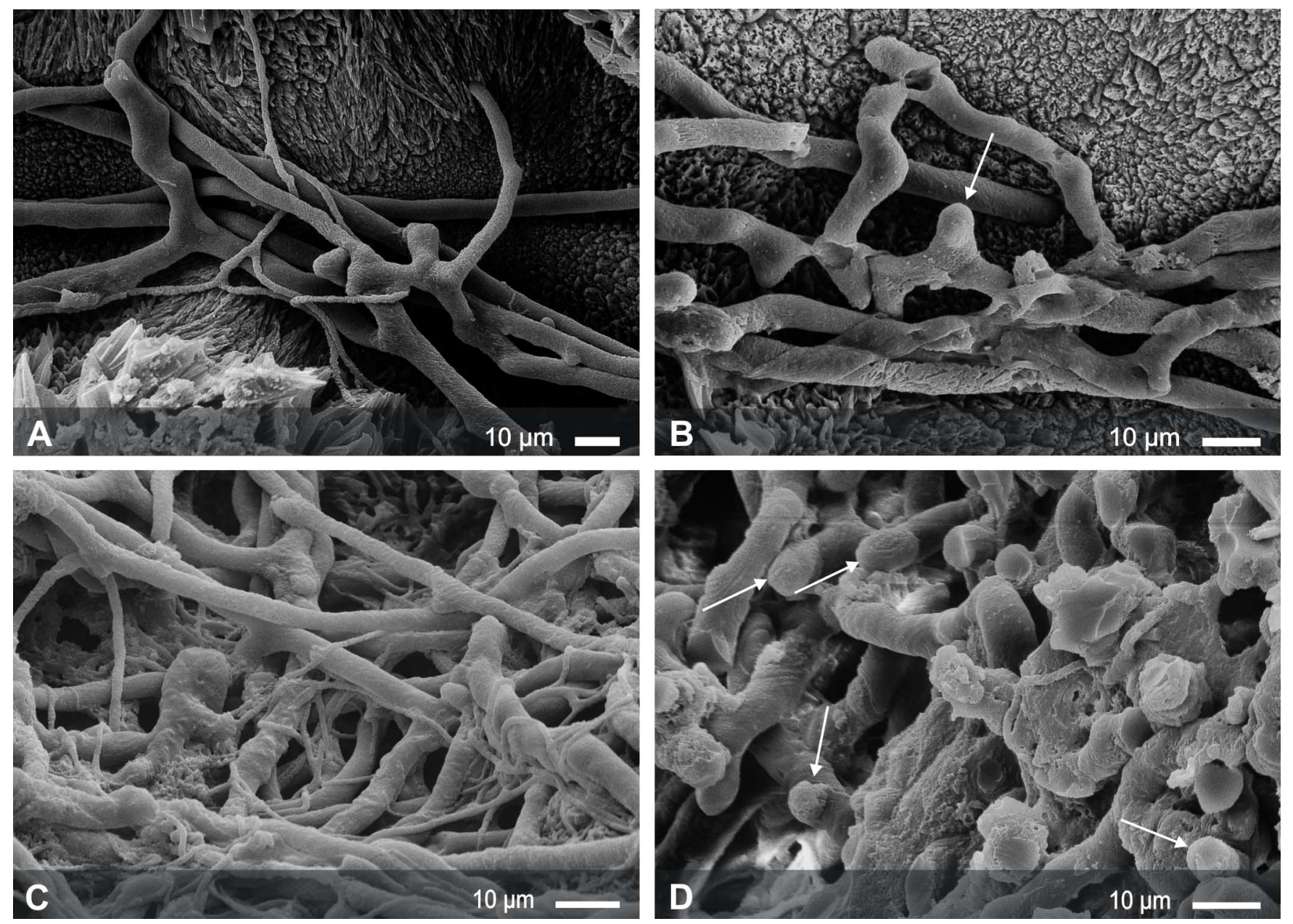
Figure F6. Scolecia filosa (SEM images of resin casts of boreholes) produced by the cyanobacterium Plectonema terebrans. S. filosa forms dense meshworks of "spaghetti-like" curved, thin, and long galleries which rarely bifurcate. The trace is recorded in (A, B) coral skeletons and (C, D) microbial crusts of the deglacial sequence of Tahitian coral reefs.
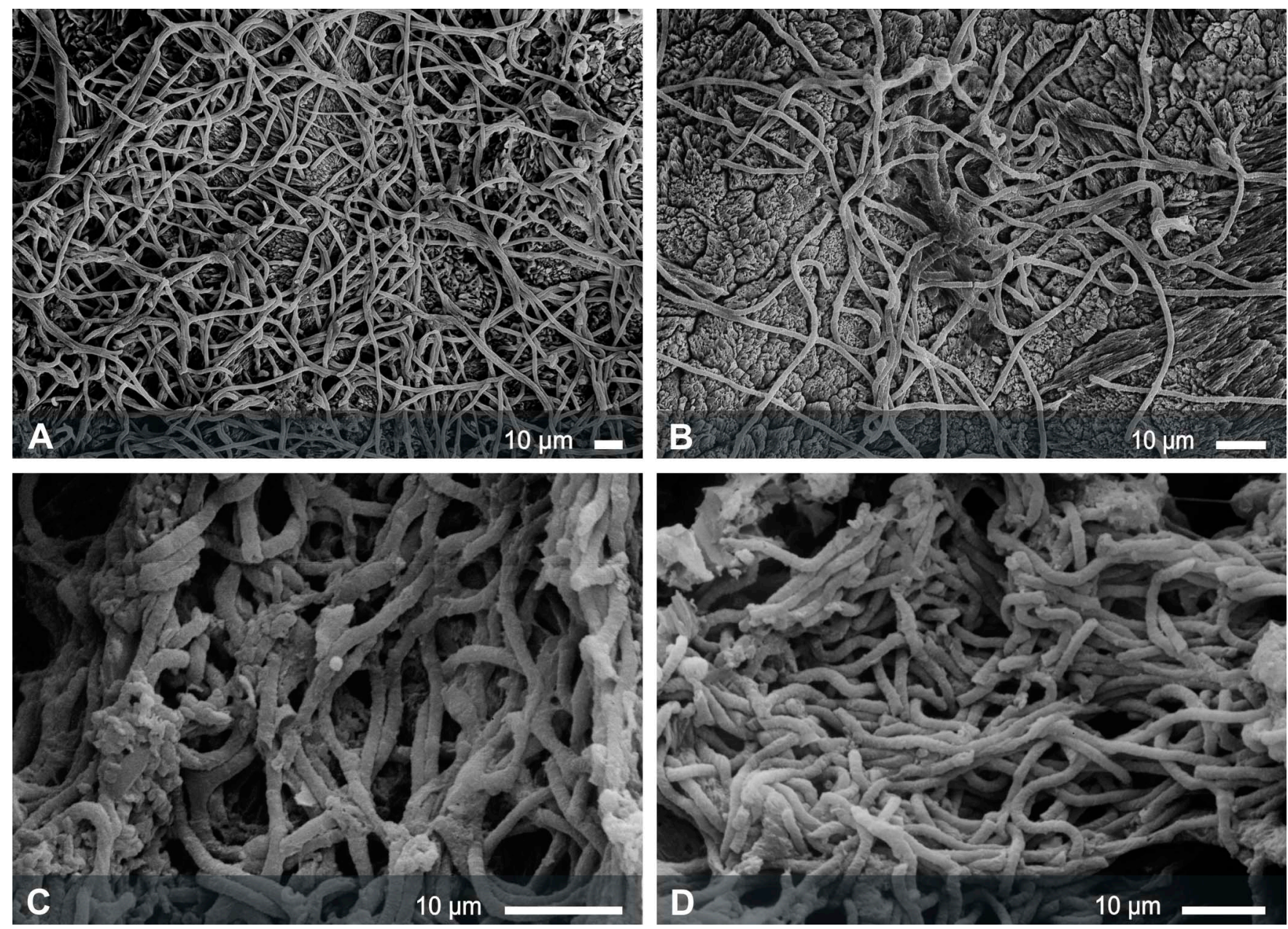
Figure F7. Rhopalia catenata (SEM images of resin casts of boreholes) produced by the chlorophyte Phaeophila dendroides. The trace shows (A, B, C) typical swellings. D. Typical appendixes connect the trace with the coral skeleton surface. $R$. catenata is exclusively reported from coral skeletons.
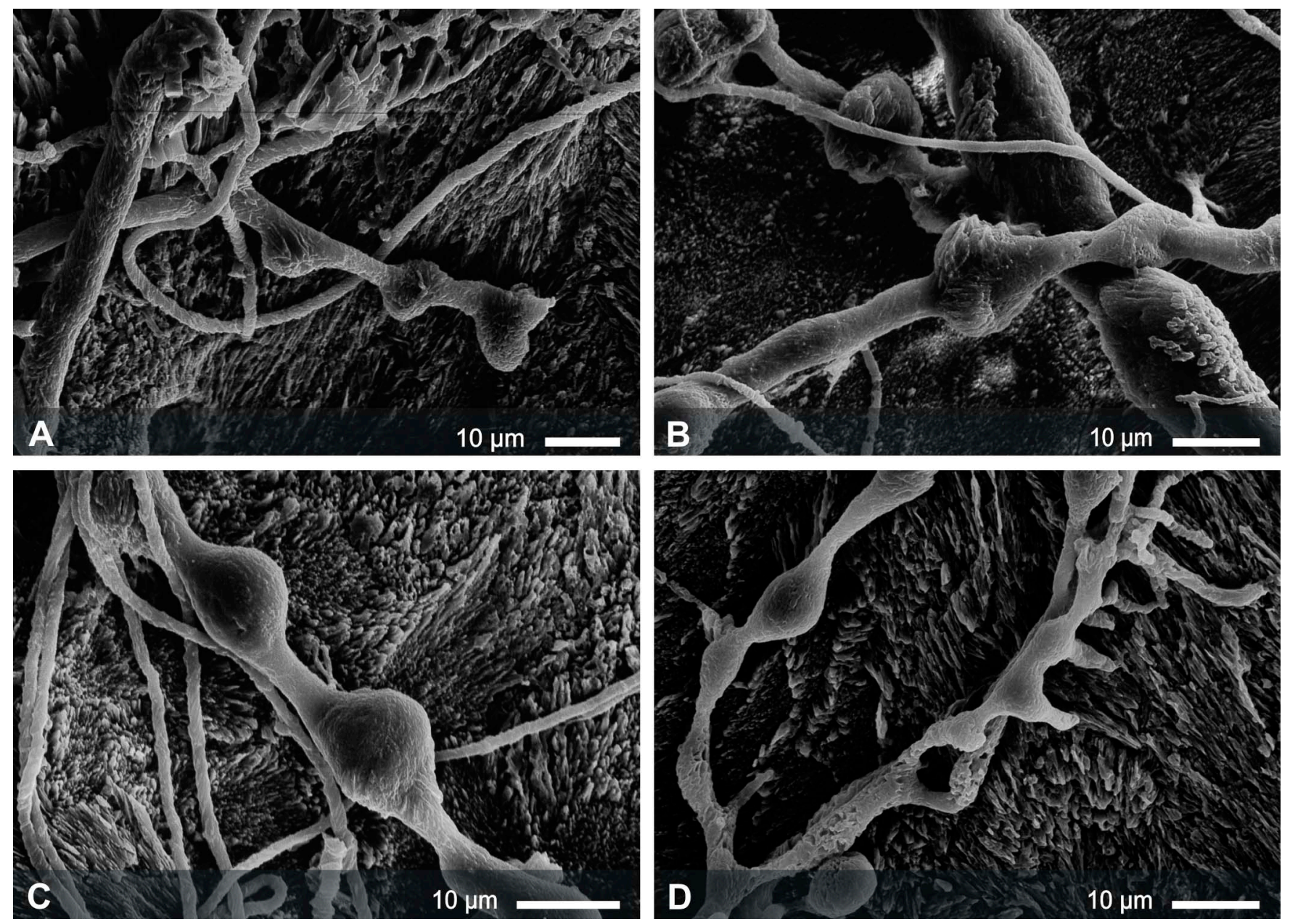
Figure F8. Ichnoreticulina elegans (SEM images of resin casts of boreholes) produced by the chlorophyte Ostreobium quekettii. Main characteristic of I. elegans is the dense zigzag pattern meshwork. A, B. The common diameter of zigzag-shaped galleries is $\sim 2 \mu \mathrm{m}$. C, D. I. elegans also develops thick galleries up to $5 \mu \mathrm{m}$ in diameter. E. Unusual little appendixes $(\leq 1 \mu \mathrm{m})$ emerge from individual thick galleries $(3-4 \mu \mathrm{m}$, triangle). Thin and straight exploratory filaments (1-2 $\mu \mathrm{m}$, arrows) extend close and parallel to the substrate surface. F. Archlike branches $(5 \mu \mathrm{m})$ which connect I. elegans to the substrate surface with an arch span of 10-20 $\mu \mathrm{m}$. I. elegans was found in all three substrates (coral, coralline algae, and microbialite).
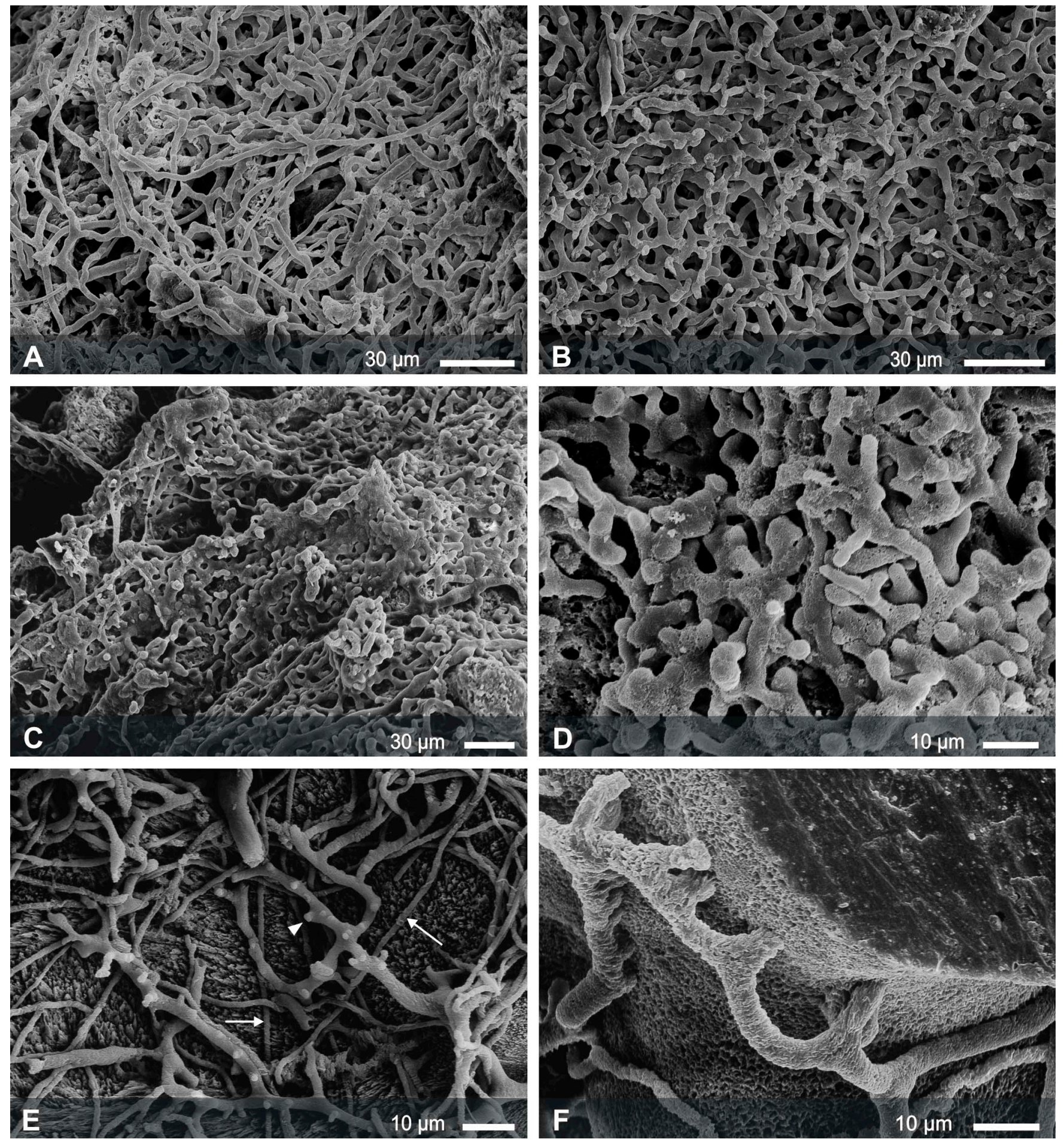
Figure F9. Saccomorpha clava (SEM images of resin casts of boreholes) produced by the fungus Dodgella priscus. Thin filaments interlinking individual $S$. clava specimens contain hyphae. They emerge from the sacks and/or the base of the necks, attached to the substrate surface. A, B. S. clava occurs in clusters of mainly club-shaped sacks (Morphotype 3). S. clava occurs as (C) scattered straight sacks (Morphotype 1) or (D) large individual branched sacks (Morphotype 4). E, F. Saccomorpha cf. clava, a trace also produced by the fungus D. priscus is longer and slightly thicker than S. clava. E. The trace is developed as clusters of curved sacks (Morphotypes 2 and 3). F. S. cf. clava is developed as a large individual branched sack (Morphotype 4). S. clava was found in all three substrates (coral, coralline algae, and microbialite), whereas $S$. cf. clava was found in corals and microbialites.
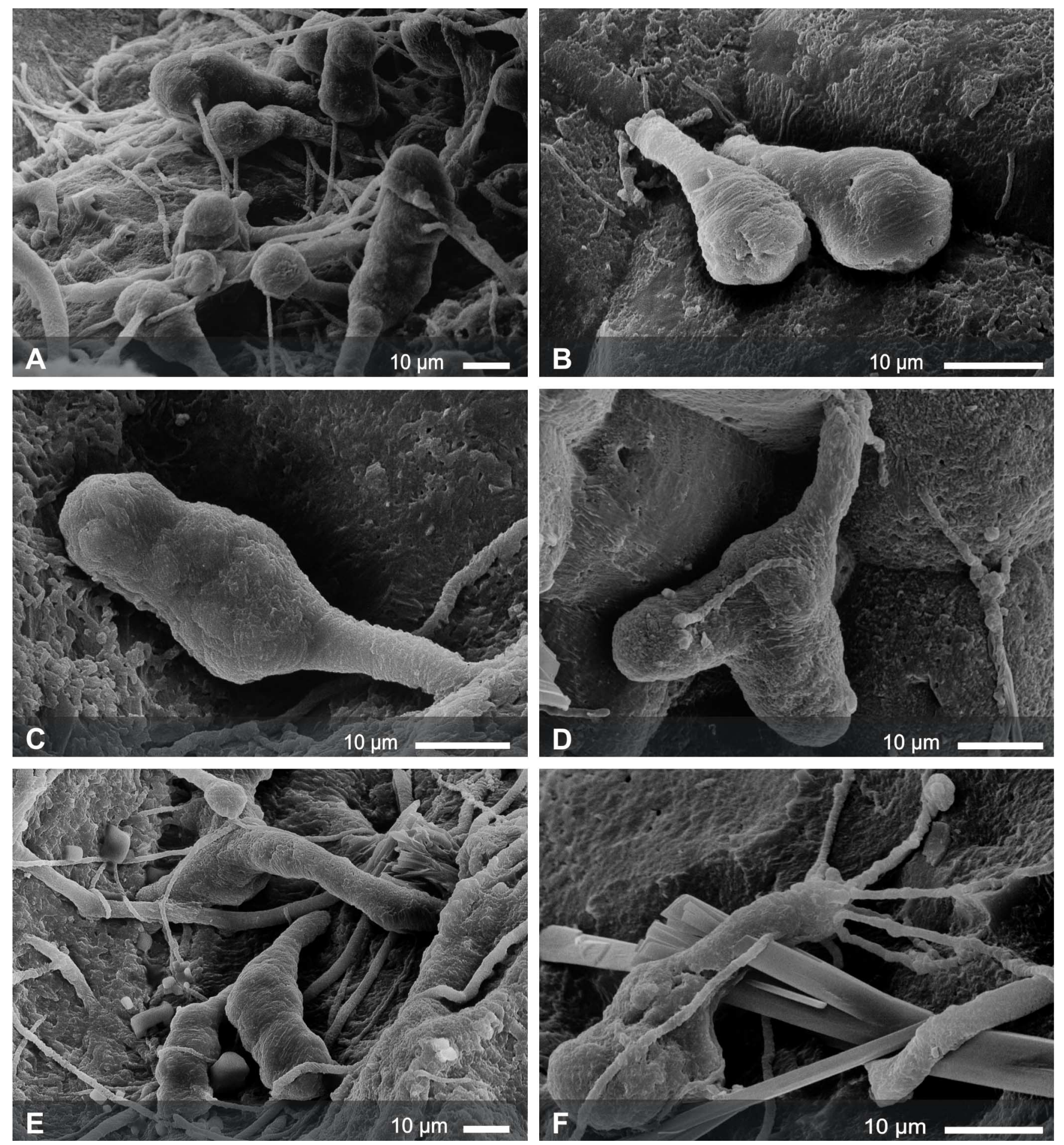
Figure F10. A, B. Orthogonum fusiferum (SEM images of resin casts of boreholes) produced by the fungus Ostracoblabe implexa. Typical swellings develop at bifurcations with commonly right angles (arrows in A) or along thin and mostly straight galleries (upper right arrow in A and arrow in B). O. fusiferum was solely found in coral skeletons.
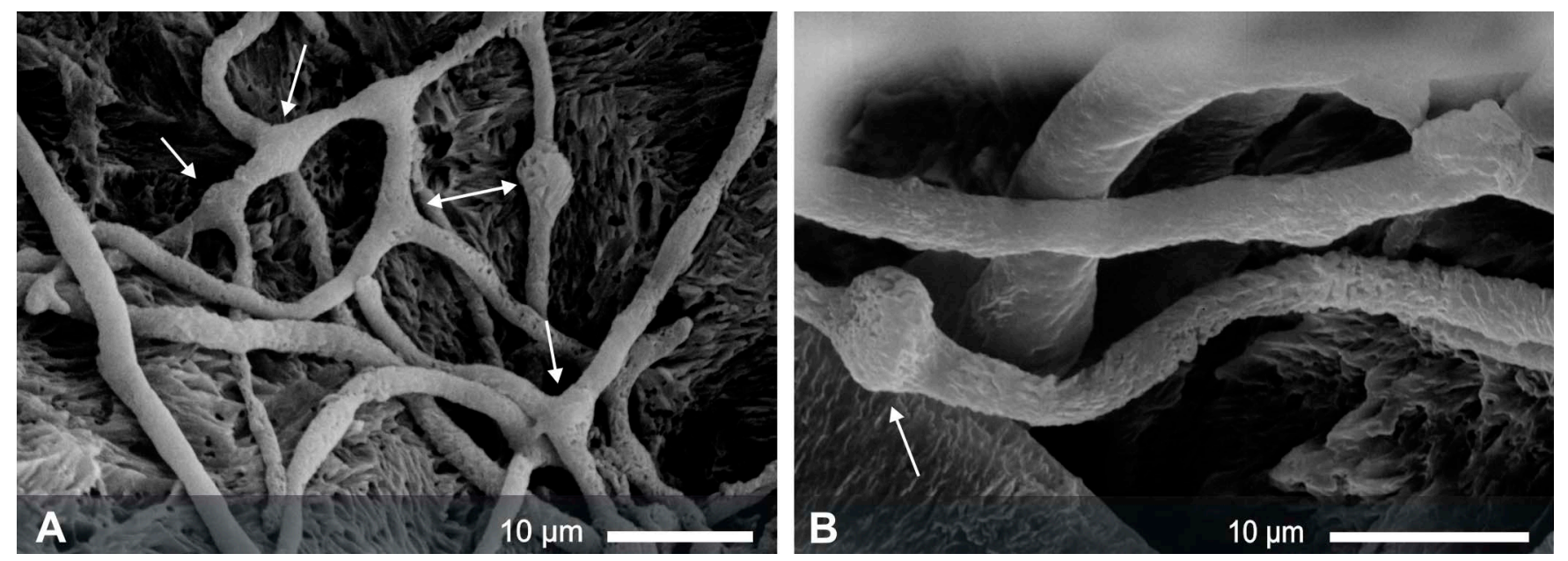
Figure F11. A-F. Scolecia serrata (SEM images of resin casts of boreholes) produced by an unknown bacterium. $S$. serrata forms dense and compact networks with rare bifurcations and shows the typical serrate microsculpture. E. Within this study, S. serrata was found frequently associated with Ichnoreticulina elegans. S. serrata was found in all three substrates (coral, coralline algae, and microbialite).
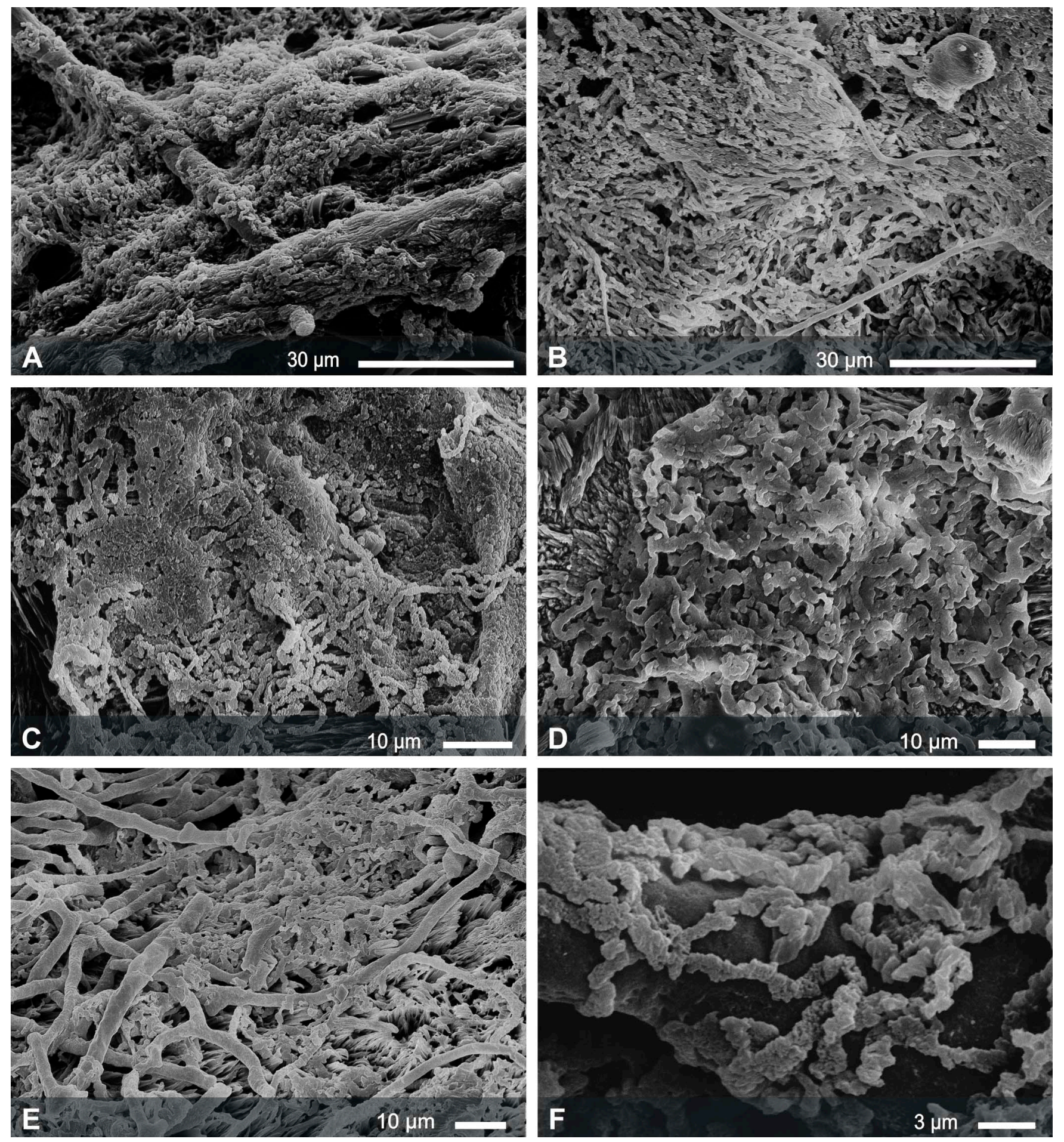
Figure F12. A-F. Scolecia cf. serrata (SEM images of resin casts of boreholes) is regarded as morphological variant of S. serrata. S. cf. serrata shows the same characteristics as S. serrata (Fig. F11) but the galleries are slightly thicker (clearly visible in D and E). The supposed association with a spherelike trace such as Saccomorpha sphaerula is eye-catching. The spherical aggregates ("bags of wool;" arrows in A and B) are produced by $S$. cf. serrata twining around the assumed spherical fungal traces. The fungal traces might be indicated by thin hyphae emerging from the bags of wool (arrows in C-F). S. cf. serrata was exclusively recorded inside coral skeleton.
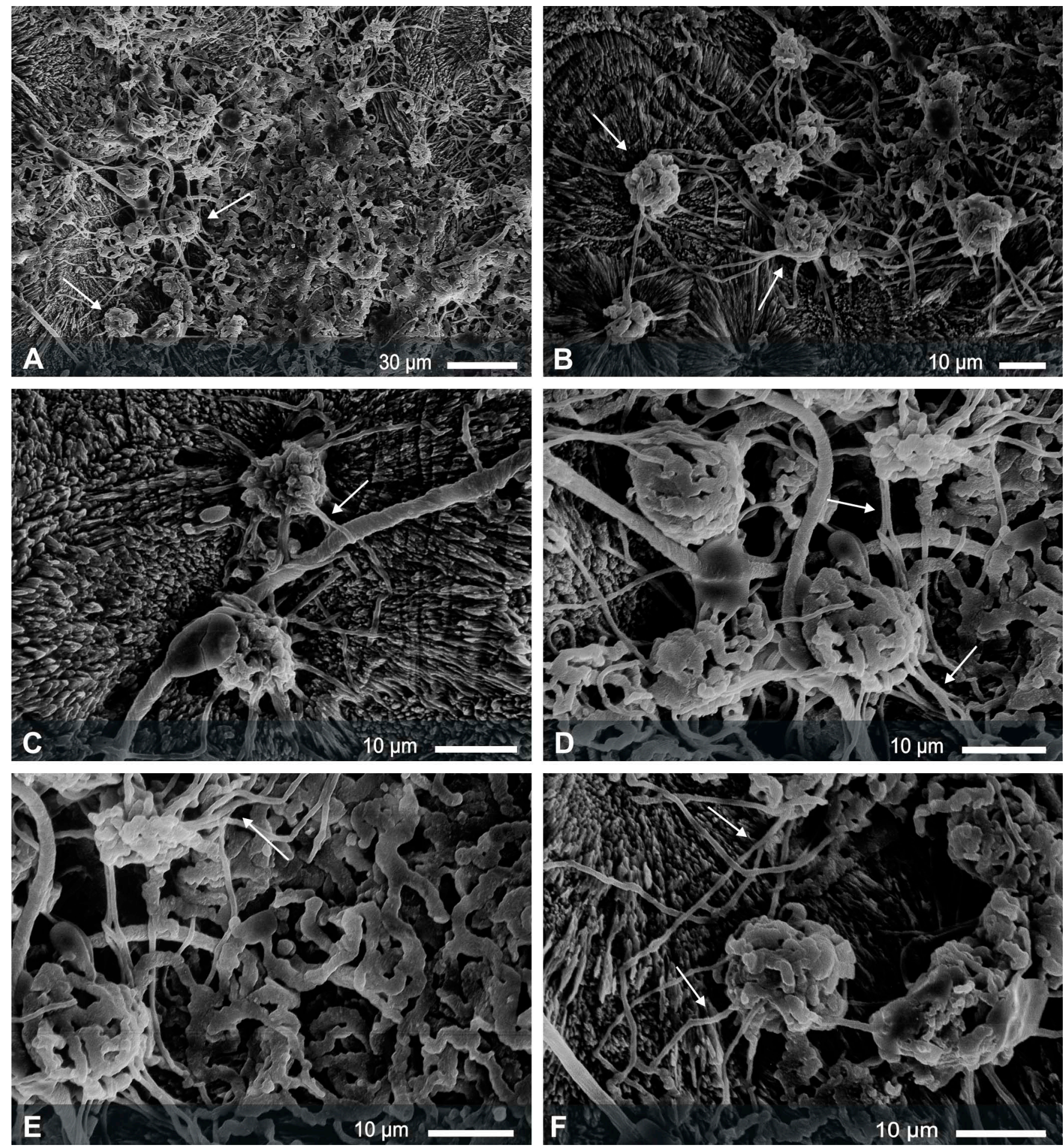
Figure F13. Orthogonum lineare (SEM images of resin casts of boreholes) produced by an unknown heterotrophic organism. A, B. The parallel run of the galleries to Entobia boring cells and/or coralline algae cells produces the uncommon zigzaglike course of $O$. lineare. Apophyses emerge from the main galleries (arrows in $\mathrm{B}$ and $\mathrm{D})$. C, D. Within this study, $O$. lineare is abundantly not smooth but rather verrucose. The diagnostic perpendicular bifurcation pattern is not illustrated. O. lineare was found in all three substrates (coral, coralline algae, and microbialite).
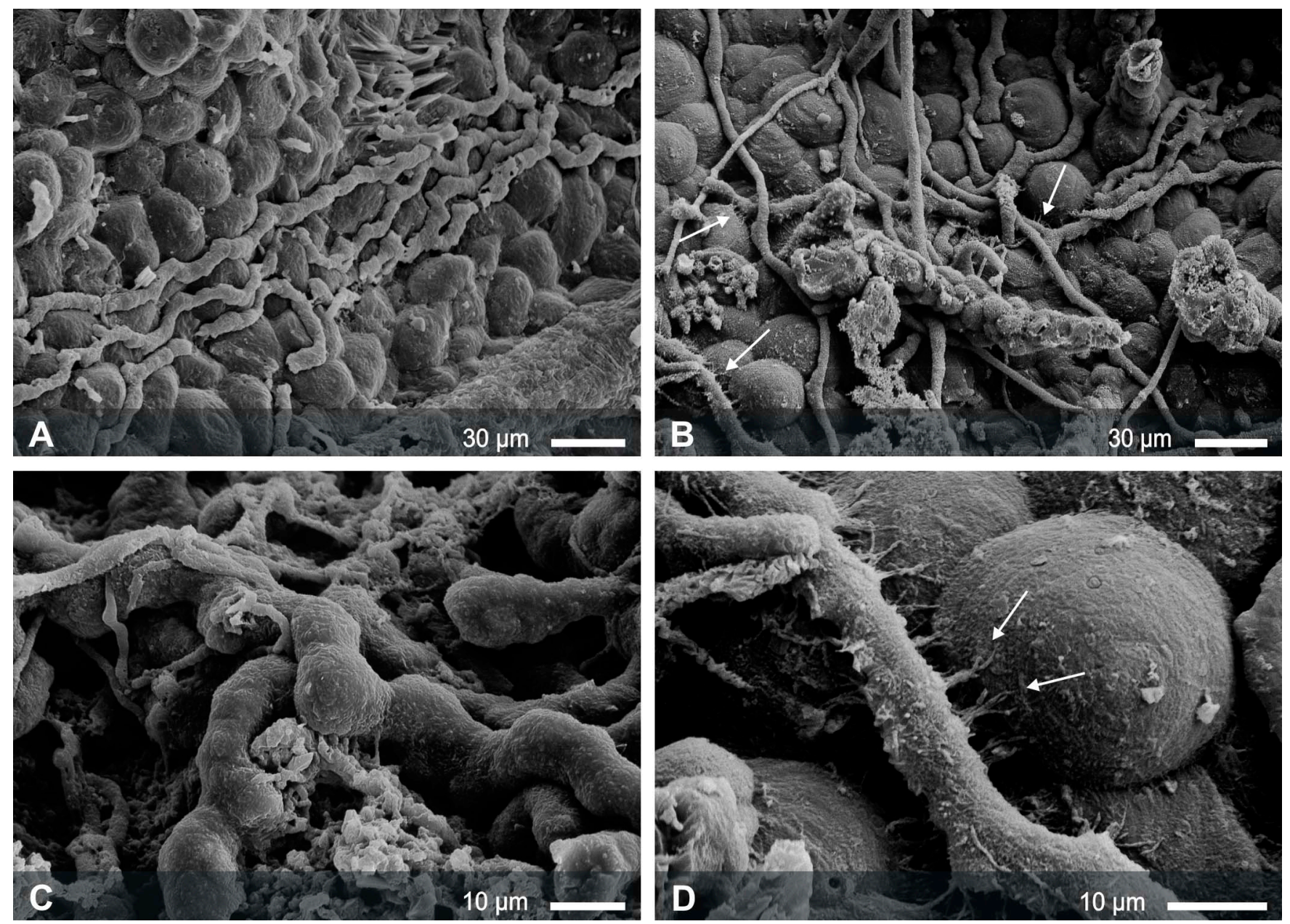
Figure F14. The producer of Dendrinid-form (SEM images of resin casts of boreholes) is unknown but trace shows characteristics of a dendrinid ichnospecies (ichnofamily Dendrinidae; Bromley et al. 2007). A, B. Dense zigzag-shaped network originates from a central gallery in a dendriniform pattern (arrow in A = central gallery) that bifurcates often at right angles. C, D. The surface of individual galleries appears rough. Dendrinid-form was reported solely in Entobia cavities.
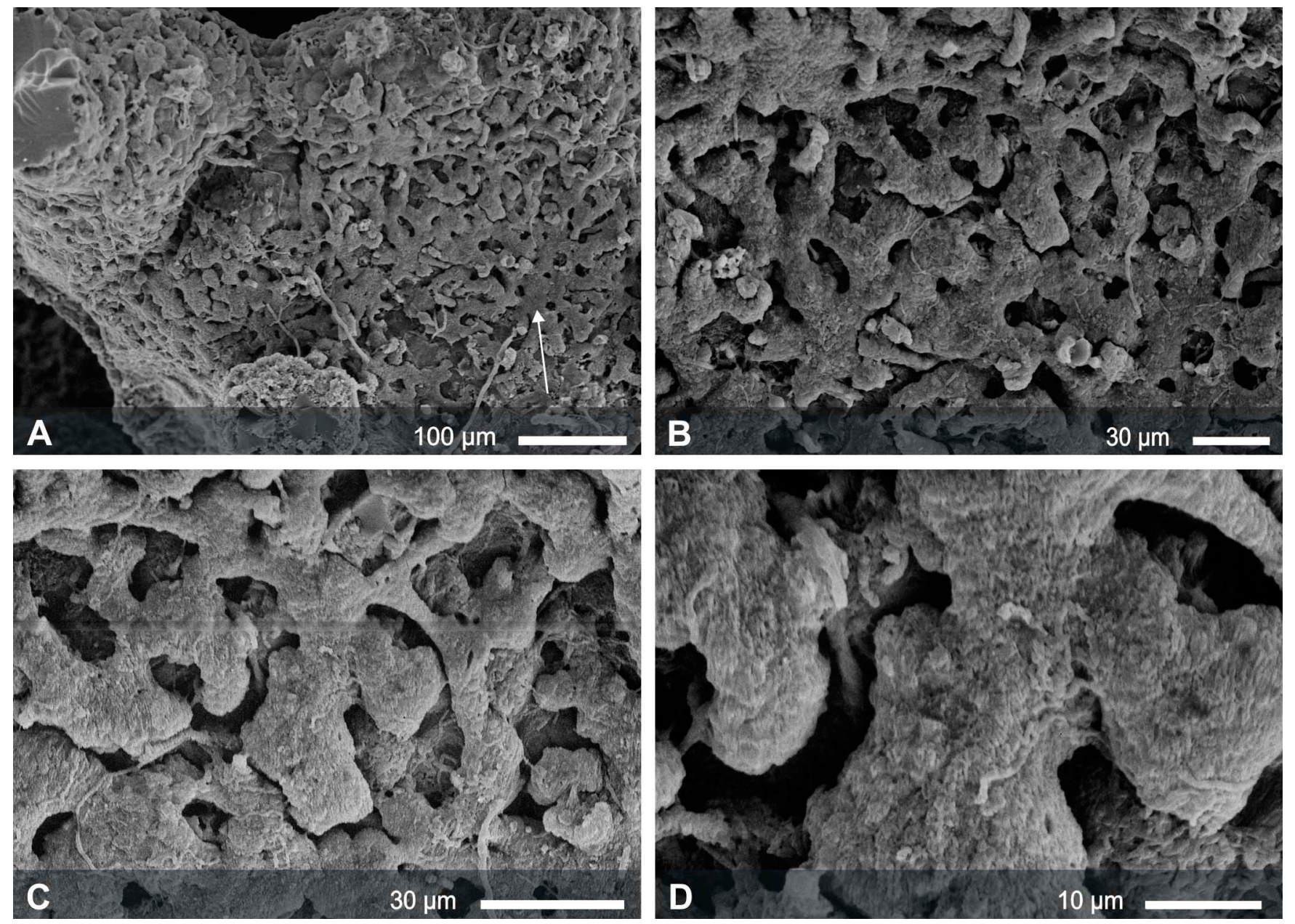
Figure F15. A-D. Worm-form (SEM images of resin casts of boreholes) is a potential microboring with unknown producer. Complex morphology is formed by repetitive and to the distal end widening galleries that decrease in size from the basal to the distal galleries. Worm-form was found only in microbial crusts.
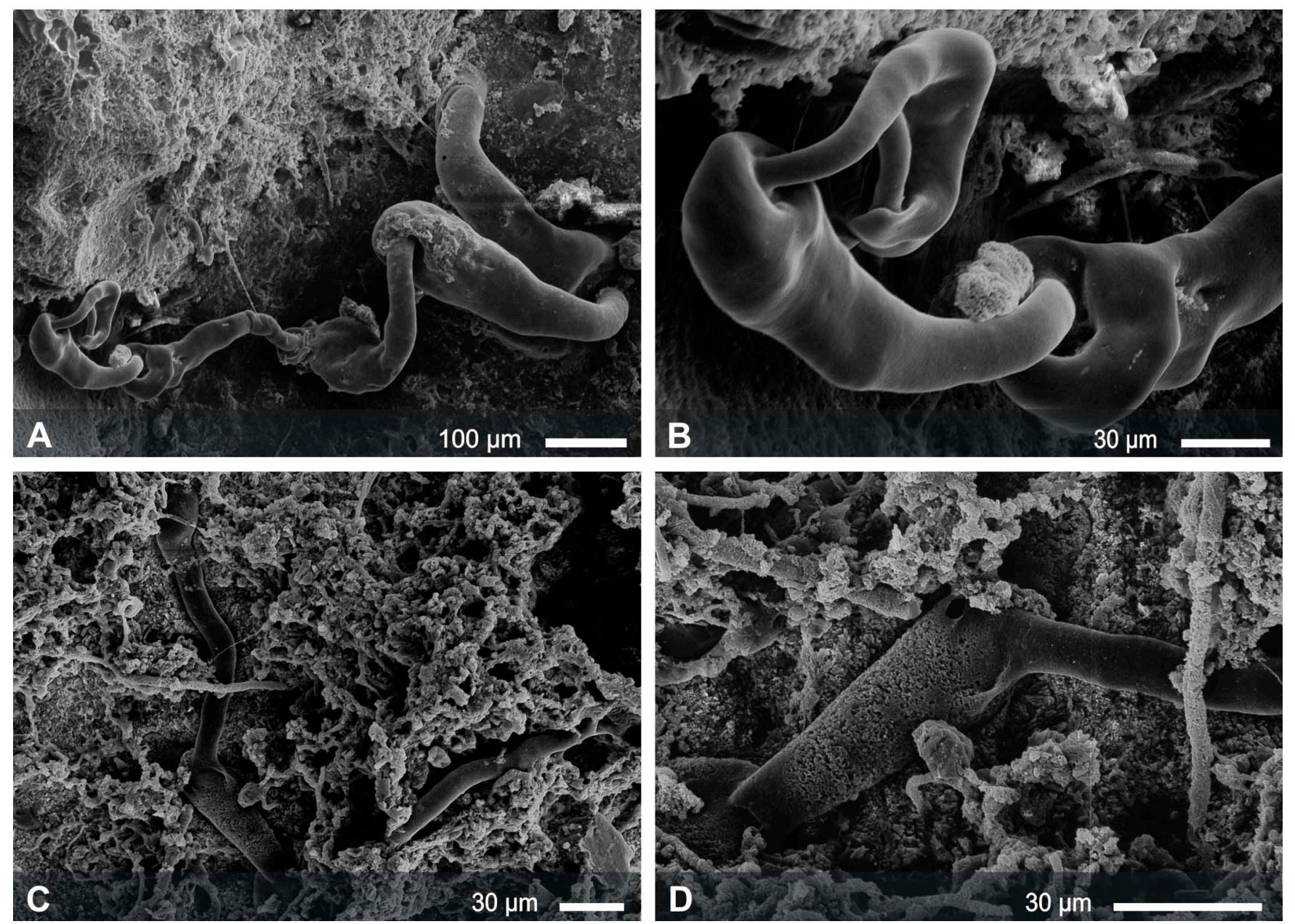
Figure F16. Deepening-up with final drowning of deglacial reef sequence indicated by microbioerosion. Faaa $=$ Hole M0019A; Maraa $=$ Holes M0007B, M0017A, M0015A, M0016A, and M0018A; Tiarei inner ridge $=$ Hole M0023A; Tiarei outer ridge $=$ Holes M0009D, M0009E, M0024A, M0025A, M0025B, M0021B, and M0009B. Base of deglacial reef represents euphotic conditions indicated by typical microbioeroders in corals. Cryptophotic conditions indicated by typical microborers are locally developed in shaded niches within the photic zone (Cores 310-M0025A-9R-1, 310M0025B-10R-1, and 310-M0007B-11R-1). Toward the top of deglacial reef, euphotic indications change to dysphotic indications which traces the post-LGM sea level rise. Yellow = deglacial reef $($ Unit 1$)$, gray = older Pleistocene $($ Unit 2$)$. DRS = deglacial reef succession. Cryptoph $=$ cryptophotic.

SE

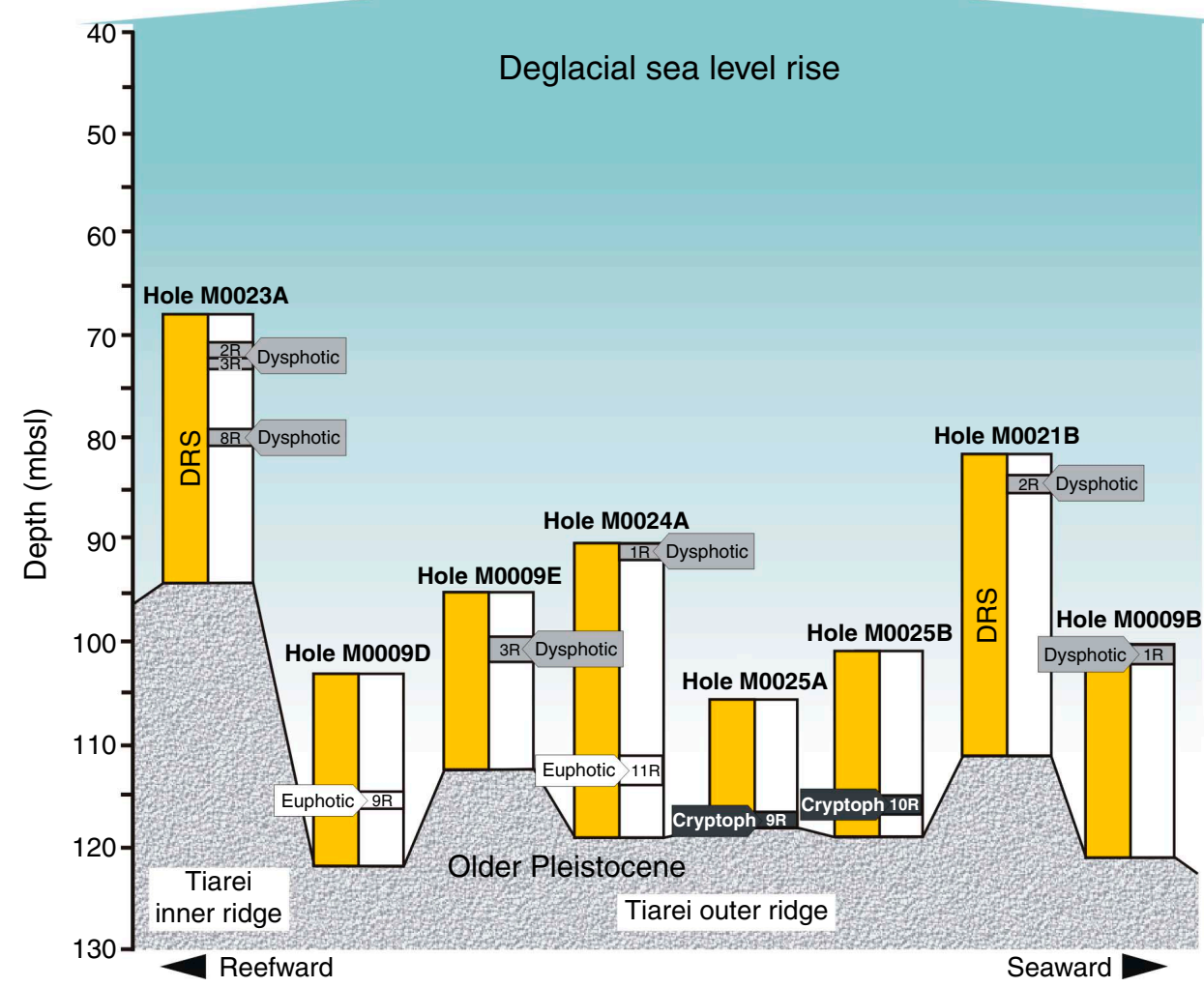

NW

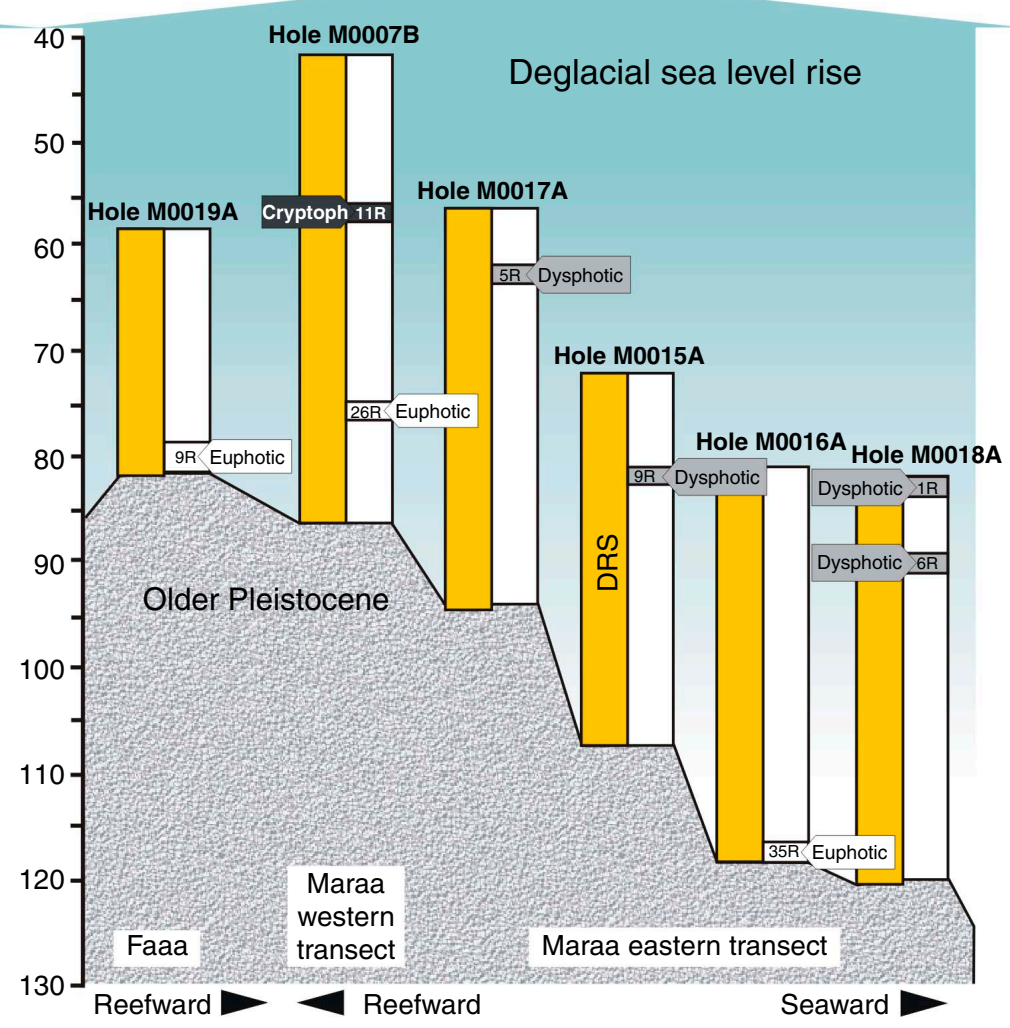


Table T1. Position, water depth of the top of the hole, and total water depth of drilled boreholes.

\begin{tabular}{|c|c|c|c|c|c|}
\hline \multirow[b]{2}{*}{ Site } & \multirow[b]{2}{*}{ Hole } & \multirow[b]{2}{*}{ Latitude } & \multirow[b]{2}{*}{ Longitude } & \multicolumn{2}{|c|}{ Depth (mbsl) } \\
\hline & & & & Water & Total \\
\hline & $310-$ & & & & \\
\hline \multirow[t]{8}{*}{ Tiarei } & M0009B & $17^{\circ} 29.3153^{\prime} S$ & $149^{\circ} 24.2044^{\prime} \mathrm{W}$ & 100.31 & 127.43 \\
\hline & M0009D & $17^{\circ} 29.3153^{\prime} \mathrm{S}$ & $149^{\circ} 24.2011^{\prime} \mathrm{W}$ & 103.18 & 147.77 \\
\hline & M0009E & $17^{\circ} 29.3153^{\prime} \mathrm{S}$ & $149^{\circ} 24.2121^{\prime} \mathrm{W}$ & 94.94 & 115.44 \\
\hline & M0021B & $17^{\circ} 29.3427^{\prime} S$ & $149^{\circ} 24.1692^{\prime} \mathrm{W}$ & 81.70 & 114.51 \\
\hline & M0023A & $17^{\circ} 29.4169^{\prime} \mathrm{S}$ & $149^{\circ} 24.2770^{\prime} \mathrm{W}$ & 67.98 & 99.34 \\
\hline & M0024A & $17^{\circ} 29.2918^{\prime} \mathrm{S}$ & $149^{\circ} 24.2358^{\prime} \mathrm{W}$ & 90.44 & 122.74 \\
\hline & M0025A & $17^{\circ} 29.2815^{\prime} \mathrm{S}$ & $149^{\circ} 24.2420^{\prime} \mathrm{W}$ & 105.40 & 126.33 \\
\hline & M0025B & $17^{\circ} 29.2862^{\prime} \mathrm{S}$ & $149^{\circ} 24.1679^{\prime} \mathrm{W}$ & 100.84 & 121.34 \\
\hline \multirow[t]{5}{*}{ Maraa } & M0007B & $17^{\circ} 45.9462^{\prime} \mathrm{S}$ & $149^{\circ} 33.0682^{\prime} \mathrm{W}$ & 41.65 & 89.88 \\
\hline & M0015A & $17^{\circ} 46.0445^{\prime} \mathrm{S}$ & $149^{\circ} 32.8499^{\prime} \mathrm{W}$ & 72.15 & 114.33 \\
\hline & M0016A & $17^{\circ} 46.0534^{\prime} \mathrm{S}$ & $149^{\circ} 32.8565^{\prime} \mathrm{W}$ & 80.85 & 119.16 \\
\hline & M0017A & $17^{\circ} 46.0124^{\prime} \mathrm{S}$ & $149^{\circ} 32.8433^{\prime} \mathrm{W}$ & 56.45 & 97.01 \\
\hline & M0018A & $17^{\circ} 46.0416^{\prime} \mathrm{S}$ & $149^{\circ} 32.8959^{\prime} \mathrm{W}$ & 81.80 & 121.85 \\
\hline Faaa & M0019A & $17^{\circ} 32.0799^{\prime} \mathrm{S}$ & $149^{\circ} 35.9195^{\prime} \mathrm{W}$ & 58.75 & 125.71 \\
\hline
\end{tabular}

Table T2. Sample code, water depth, and position of analyzed samples, IODP Expedition 310. (See table note.)

\begin{tabular}{|c|c|c|c|}
\hline Site & $\begin{array}{l}\text { Hole, core, section, } \\
\text { interval }(\mathrm{cm})\end{array}$ & $\begin{array}{l}\text { Water } \\
\text { depth } \\
\text { (mbsl) }\end{array}$ & $\begin{array}{c}\text { Sample position } \\
\text { in deglacial reef } \\
\text { succession }\end{array}$ \\
\hline & $310-$ & & \\
\hline \multirow[t]{11}{*}{ Tiarei } & M0023A-2R-1, 40-47 & 71 & Top \\
\hline & M0023A-3R-1, 10-12 & 72 & Top \\
\hline & M0023A-8R-1, 5-41 & 79 & Middle \\
\hline & M0021B-2R-1, 96-103 & 83 & Middle \\
\hline & M0024A-1R-1, 3-6 & 91 & Middle \\
\hline & M0009E-3R-1, 99-110 & 96 & Middle \\
\hline & M0009B-1R-1, 33-46 & 100 & Middle \\
\hline & M0024A-11R-2, 73-89 & 111 & Base \\
\hline & M0009D-9R-1, 108-114 & 114 & Base \\
\hline & M0025B-10R-1, 62-69 & 115 & Base \\
\hline & M0025A-9R-1, 22-29 & 117 & Base \\
\hline \multirow[t]{7}{*}{ Maraa } & M0017A-5R-1, 28-32 & 64 & Top \\
\hline & M0007B-11R-1, 54-60 & 56 & Top \\
\hline & M0015A-9R-1, 6-10 & 81 & Middle \\
\hline & M0018A-1R-1, 41-47 & 82 & Middle \\
\hline & M0018A-6R-1, 6-10 & 89 & Middle \\
\hline & M0007B-26R-1, 77-92 & 75 & Base \\
\hline & M0016A-35R-1, 23-27 & 116 & Base \\
\hline Faaa & M0019A-9R-1, 65-70 & 78 & Base \\
\hline
\end{tabular}

Note: Top $=$ youngest sequences, middle $=$ middle ranges, base $=$ oldest sequences 
Table T3. Base of Tahitian deglacial reef succession. (See table notes.)

\begin{tabular}{|c|c|c|c|c|c|c|c|c|c|c|c|c|c|}
\hline \multirow[b]{2}{*}{ Site } & \multirow[b]{2}{*}{$\begin{array}{l}\text { Hole, core, section, } \\
\text { interval }(\mathrm{cm})\end{array}$} & \multirow{2}{*}{ 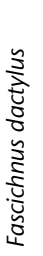 } & \multirow{2}{*}{ 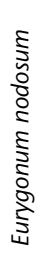 } & \multirow{2}{*}{ 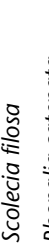 } & \multirow{2}{*}{ 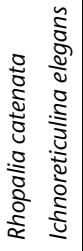 } & & \multirow{2}{*}{ 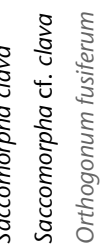 } & \multirow{2}{*}{ 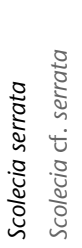 } & \multirow{2}{*}{\multicolumn{2}{|c|}{ 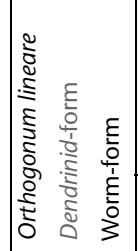 }} & \multicolumn{3}{|c|}{ Photic indication } \\
\hline & & & & & & & & & & & Corals & $\begin{array}{l}\text { Coralline } \\
\text { algal crusts }\end{array}$ & Microbialites \\
\hline Tiarei & $\begin{array}{l}310- \\
\text { M0025A-9R-1, 22-29 } \\
\text { M0025B-10R-1, 62-69 } \\
\text { M0009D-9R-1, 108-114 } \\
\text { M0024A-11R-2, 73-89 }\end{array}$ & & $\begin{array}{l}\mathrm{C} \\
\mathrm{C}\end{array}$ & $\begin{array}{l}\mathrm{C} \\
\mathrm{C}\end{array}$ & C & , & $\mathrm{R}$ & $\begin{array}{l}\mathrm{R} \\
\mathrm{R}\end{array}$ & $\begin{array}{l}\mathrm{C} \\
\mathrm{R}\end{array}$ & $\mathrm{R}$ & $\begin{array}{l}\text { cry } \\
\text { cry } \\
\text { eu II, deu } \\
\text { eu II, deu }\end{array}$ & $\begin{array}{l}- \\
\text { dys } \\
\text { dys }\end{array}$ & $\begin{array}{l}\text { - } \\
\text { cry } \\
\text { dys } \\
\text { cry }\end{array}$ \\
\hline Maraa & $\begin{array}{l}\text { M0016A-35R-1, 23-27 } \\
\text { M0007B-26R-1, 77-92 }\end{array}$ & $\begin{array}{l}\mathrm{C} \\
\mathrm{R}\end{array}$ & & A & $A A$ & & & C & & & $\begin{array}{l}\text { eu II, deu } \\
\text { eu II, deu }\end{array}$ & dys & $\begin{array}{l}\text { dys } \\
\text { dys }\end{array}$ \\
\hline Faaa & M0019A-9R-1, 65-70 & C & $\mathrm{C}$ & $\mathrm{C}$ & & & & & $\mathrm{R}$ & & eu II, deu & - & - \\
\hline
\end{tabular}

Notes: Semiquantitative analysis of microborer traces observed by SEM in corals, coralline algal crusts, and microbialites. Gray text = traces that are completely absent in the reef succession of the base. Photic indication = paleobathymetric interpretation derived from the ichnocoenosis in each sample. $\mathrm{A}=$ abundant, $\mathrm{C}=$ common, $\mathrm{R}=$ rare. $\mathrm{Cry}=$ cryptophotic conditions, $-=$ no microbioerosion, eu II = shallow euphotic Zone II conditions, deu = deep euphotic conditions, dys = dysphotic conditions.

Table T4. Middle ranges of Tahitian deglacial reef succession. (See table notes.)

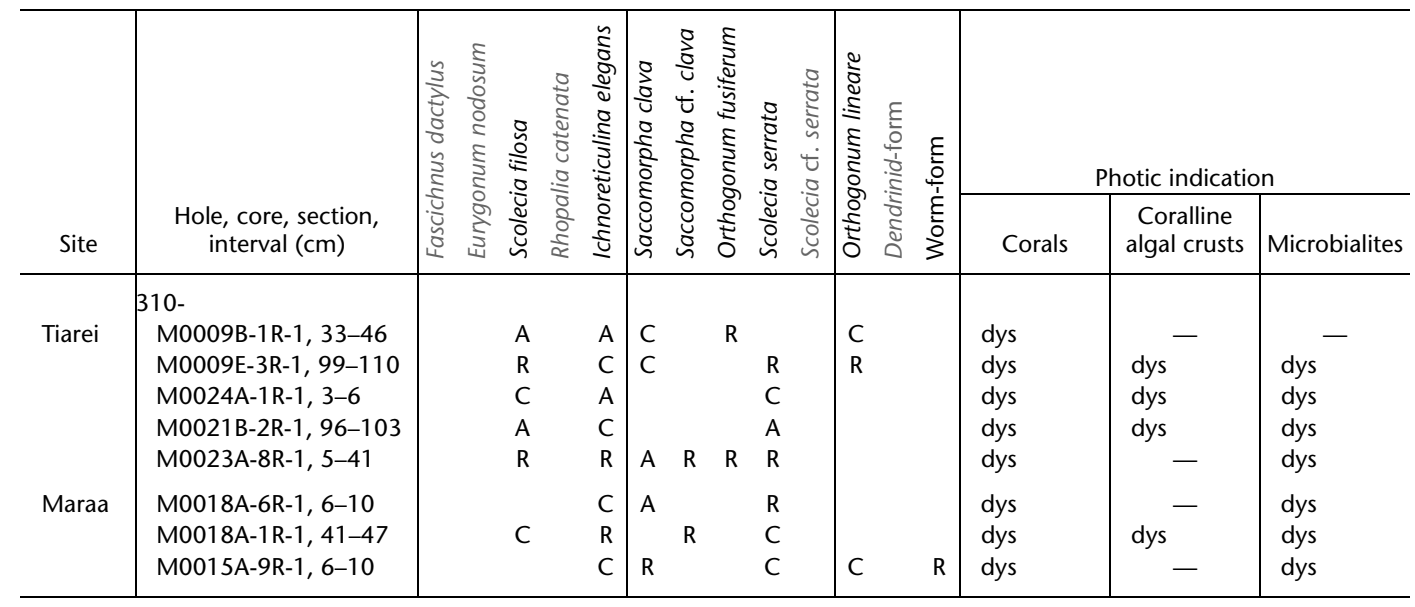

Notes: Semiquantitative analysis of microborer traces observed by SEM in corals, coralline algal crusts, and microbialites. Gray text $=$ traces that are completely absent in the reef succession of the middle ranges. Photic indication = paleobathymetric interpretation derived from the ichnocoenosis in each sample. $\mathrm{A}=$ abundant, $\mathrm{C}=$ common, $\mathrm{R}=$ rare. Dys = dysphotic conditions,$-=$ no microbioerosion. 
Table T5: Top of Tahitian deglacial reef succession. (See table notes.)

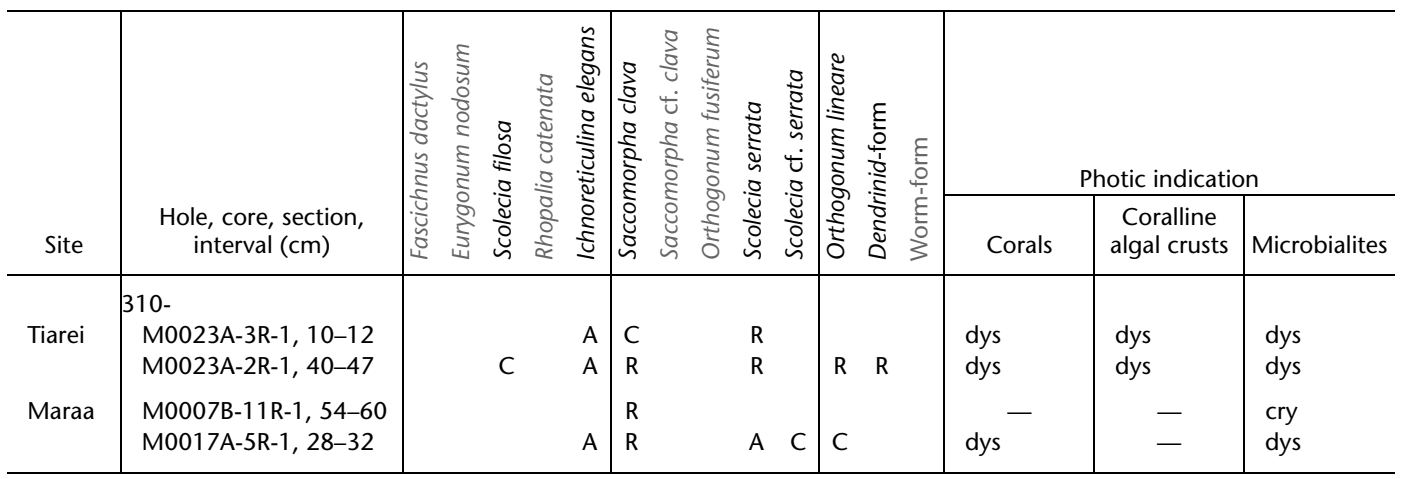

Notes: Semiquantitative analysis of microborer traces observed by SEM in corals, coralline algal crusts, and microbialites. Gray text $=$ traces that are completely absent in the reef succession of the top. Photic indication = paleobathymetric interpretation derived from the ichnocoenosis in each sample. $\mathrm{A}=$ abundant, $\mathrm{C}=$ common, $\mathrm{R}=$ rare. Dys $=$ dysphotic conditions,$-=$ no microbioerosion, cry = cryptophotic conditions. 